\title{
Implications of the polymorphism of HLA-G on its function, regulation, evolution and disease association
}

\author{
Eduardo A. Donadi - Erick C. Castelli • \\ Antonio Arnaiz-Villena · Michel Roger • \\ Diego Rey $\cdot$ Philippe Moreau
}

Received: 21 October 2010/Accepted: 22 October 2010/Published online: 24 November 2010

(C) The Author(s) 2010. This article is published with open access at Springerlink.com

\begin{abstract}
The $H L A-G$ gene displays several peculiarities that are distinct from those of classical HLA class I genes. The unique structure of the HLA-G molecule permits a restricted peptide presentation and allows the modulation of the cells of the immune system. Although polymorphic sites may potentially influence all biological functions of HLA-G, those present at the promoter and $3^{\prime}$ untranslated regions have been particularly studied in experimental and pathological conditions. The relatively low polymorphism observed in the MHC-G coding region both in humans and apes may represent a strong selective pressure for invariance, whereas, in regulatory regions several lines of evidence support the role of balancing selection. Since HLA-G has immunomodulatory properties, the understanding of gene regulation and the role of polymorphic sites on gene function may permit an individualized
\end{abstract}

E. A. Donadi $(\bowtie) \cdot$ E. C. Castelli

Division of Clinical Immunology, Department of Medicine, School of Medicine of Ribeirão Preto, University of São Paulo, Av. Bandeirantes, 3900, 14049-900 Ribeirão Preto, SP, Brazil e-mail: eadonadi@fmrp.usp.br

A. Arnaiz-Villena · D. Rey

Department of Immunology, University Complutense,

The Madrid Regional Blood Center, Madrid, Spain

M. Roger

Laboratoire d'Immunogénétique, Centre de Recherche du Centre Hospitalier de l'Université de Montréal, Montreal, Canada

P. Moreau

Commissariat à l'Energie Atomique/DSV/I2BM/Service de Recherches en Hémato-Immunologie, IUH, Hôpital Saint-Louis, 75010 Paris, France approach for the future use of HLA-G for therapeutic purposes.

Keywords HLA-G · Polymorphism · Regulation ·

Evolution · Transplantation - Tumor - Autoimmunity ·

Chronic viral infections $\cdot$ Primate evolution $\cdot$ MHC-G

\section{Introduction}

Well-recognized biological features of the non-classical class Ib HLA-G molecule that differ from other classical class I HLA (-A, -B and -C) molecules include: (1) limited protein variability, (2) presence of several membranebound and soluble isoforms, generated by alternative splicing of the primary transcript, (3) unique molecular structure, presenting a reduced cytoplasmic tail, (4) modulation of the immune response, and (5) restricted tissue expression. Polymorphic sites present in coding and noncoding regions of the $H L A-G$ gene may potentially affect all of these biological features. Nucleotide variability in the promoter or in the $3^{\prime}$ untranslated region ( $3^{\prime}$ UTR) may influence HLA-G levels by modifying the affinity of gene targeted sequences for transcriptional or post-transcriptional factors, respectively. Likewise, nucleotide variability in the coding region may produce conformational changes in the molecule, which may modify its major functions, i.e., interaction with cell receptors, isoform production, modulation of the immune response, polymerization features and ability to couple peptides. In this section, we highlight the major characteristics of $H L A-G$ gene polymorphic sites that are relevant for the understanding of molecule function, gene regulation and evolution, as well as the implications of these features on selected disease associations. 


\section{Nomenclature of $H L A-G$ alleles}

Compared to classical HLA class I genes that exhibit hundreds of alleles, the $H L A-G$ locus presents only a few variants. Due to the increasing number of reported HLA alleles, much effort has been devoted to standardize HLA nomenclature. Currently, an allele name may be composed of four, six or eight digits. The first two digits refer to the allele family, and the third and fourth assign the order in which the sequences were reported. Therefore, an allele that differs in these first four digits must have at least one non-synonymous nucleotide substitution, i.e., modifying the amino acid sequence of the encoded protein.

To date, $44 H L A-G$ alleles have been described, which encode 14 distinct functional proteins with all isoforms (HLA-G*0101, *0102, *0103, *0104, *0106, *0107, $* 0108, * 0109, * 0110, * 0111, * 0112, * 0114, * 0115$ and *0116) and modified proteins encoded by the $G^{*} 0105 \mathrm{~N}$ allele [1] (The International Immunogenetics DatabaseIMGT/HLA, database version 2.28.0, January 2010). Exemplifying, the $H L A-G^{*} 0101$ allele differs from $G^{*} 0103$ by a non-synonymous substitution at exon 2 , codon 31 , position 292, where ACG codes for threonine and TCG codes for serine. On the other hand, alleles exhibiting synonymous nucleotide substitutions in the coding sequence, producing no modification of the amino acid sequence of the encoded protein, are distinguished by the use of the fifth and sixth digits. The $H L A-G^{*} 010401$ and $G^{*} 010404$ alleles are typical examples. Both alleles differ at position +1827 (codon 267), where the $G^{*} 010401$ allele presents a CCG and the $\mathrm{G}^{*} 010404$ allele a CCA, both encoding the same residue of proline. Finally, distinct nucleotide sequences observed in introns or in the $3^{\prime}$ or $5^{\prime}$ untranslated regions are distinguished by adding a seventh or eighth digit. Exemplifying, the $G^{*} 01010104$ and $G^{*} 01010105$ alleles encode the same protein sequence and present the same coding sequence, except for a nucleotide exchange in intron 1 at position 99, in which $G^{*} 01010104$ presents an adenine and $G^{*} 01010105$ a guanine. Other examples can be retrieved from data illustrated in Fig. 1 .

Although the nomenclature has been quite appropriate to designate the adequate site of nucleotide substitution, because of the ever-increasing number of HLA alleles, particularly of the HLA-A and $H L A-B$ loci, in which more than 100 non-synonymous nucleotide substitutions have been described for the same allele group, the WHO Nomenclature Committee for Factors of the HLA System has decided to introduce colons (:) into allele designations to delimit the separate fields, to be used starting in April 2010 (Anthony Nolan Research Institute, http://hla. alleles.org). Then, according to the new nomenclature, the $H L A-G^{*} 01010101$ allele is designated as $H L A$ $G^{*} 01: 01: 01: 01$. Although the number of proteins encoded by all $H L A-G$ alleles is less than half the total number of alleles, the discovery of nucleotide substitutions has been continuously increasing, particularly those responsible for synonymous substitutions. Therefore, only the new nomenclature will be used throughout this review.

Due to the great number of synonymous nucleotide variations in the coding region, only few encoded proteins are described, accounting for HLA-G limited protein variability. In contrast, many polymorphic sites in promoter and $3^{\prime}$ UTR have been reported that may influence HLA-G expression.

$H L A-G$ coding region polymorphism: impact on HLA-G molecule features

Similar to classical HLA class I molecules, HLA-G presents a heavy chain, non-covalently associated with a $\beta 2$-microglobulin. The $H L A-G$ gene also shows similarity to the classical HLA loci, exhibiting 7 introns and 8 exons, coding only the heavy chain of the molecule and located at chromosome 6 , whereas $\beta 2$-microglobulin is encoded by a gene at chromosome 15. Exon 1 encodes the peptide signal, exons 2, 3 and 4, the extracellular $\alpha 1, \alpha 2$ and $\alpha 3$ domains, respectively, and exons 5 and 6 the transmembrane and the cytoplasmic domain of the heavy chain. Compared to classical class I molecules, HLA-G has a shortened cytoplasmic domain because of the presence of a premature stop codon in exon 6. Exon 7 is always absent from the mature mRNA and, due to the stop codon in exon 6 , exon 8 is not translated [2].

Based on the gametic phase (haplotypes) of 72 single nucleotide polymorphisms (SNP) observed between exon 1 and intron 6, $44 H L A-G$ coding alleles were defined (IMGT, database 2.28.0, January 2010) (Fig. 1). Considering the region between exon 1 and exon 6 , which encodes the external portion and the transmembrane region of the HLA-G molecule, all of these segments do present several nucleotide variations [1]. The heavy chain encoding region exhibits 33 SNPs; however, only 13 amino acid variations are observed, 4 of them in $\alpha 1,6$ in $\alpha 2$ and 3 in the $\alpha 3$ domain (Fig. 2). On the other hand, exons 1 and 5 both present only two synonymous nucleotide substitutions, hence the signal peptide and the transmembrane portion of the molecule are invariable. Despite the limited protein variability, amino acid substitutions may account for the biological function of HLA-G, including peptide binding, isoform production, and ability to polymerize and modulate immune system cells.

\section{Peptide-binding properties}

Nucleotide variability in the coding region of the $H L A-G$ gene is evenly distributed throughout exons 2 


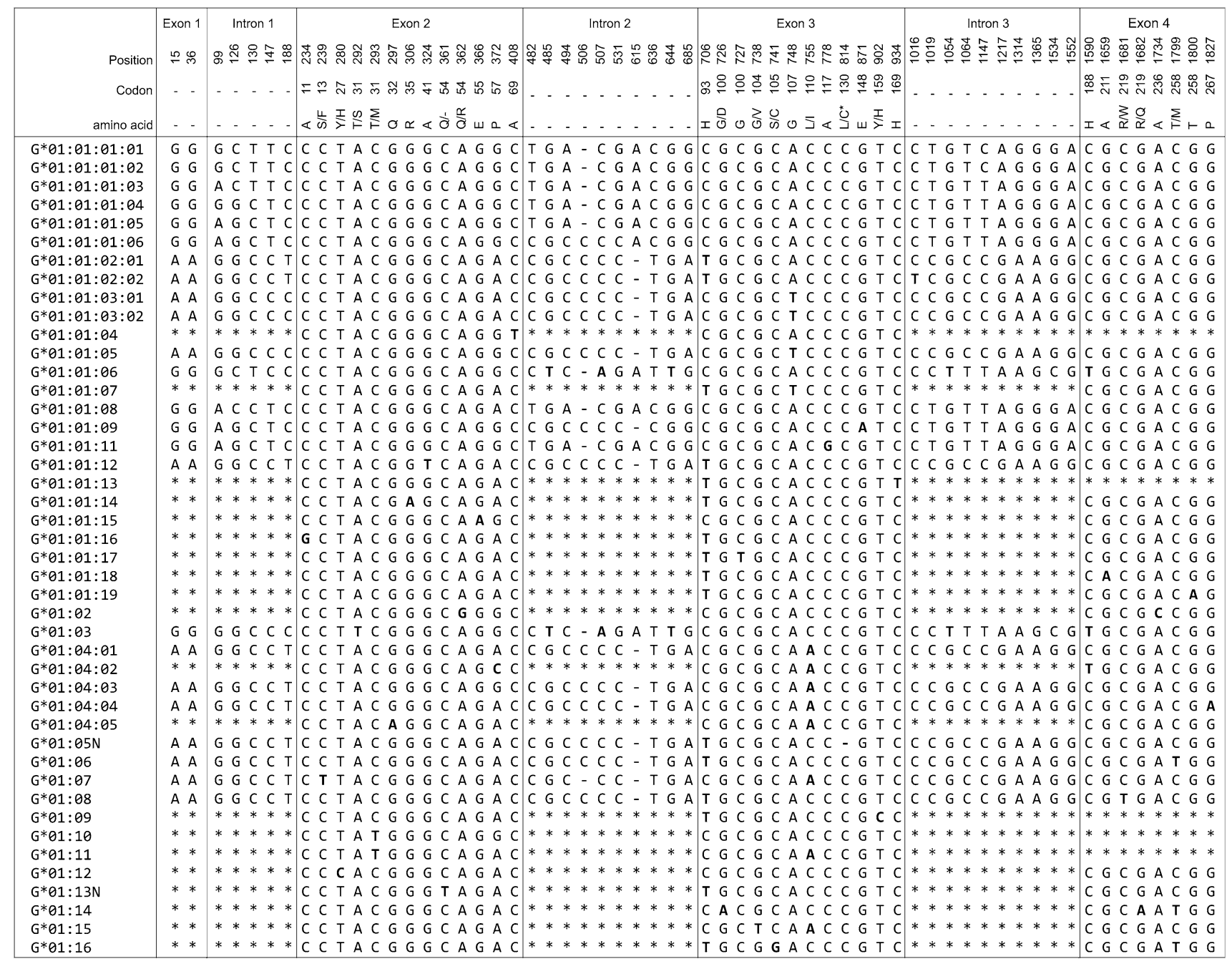

Fig. 1 Nucleotide sequences, from exon 1 to 4 , described for the 44 alleles or haplotypes observed in the coding region of the HLA-G gene (IMGT version 2.28.0, January 2010). Asterisks represent that no official information regarding these single nucleotide polymorphisms was available. Hyphen indicates deletion. Amino acid codes: $A$ alanine, $S$ serine, $F$ phenylalanine, $Y$ tyrosine, $T$ threonine, $M$ methionine, $Q$ glutamine, $R$ arginine, $E$ glutamic acid, $P$ proline, $H$ histidine, $G$ glycine, $D$ aspartic acid, $V$ valine, $C$ cysteine, $L$ leucine, $I$ isoleucine, $W$ tryptophan
Fig. 2 HLA-G $\alpha 1, \alpha 2$ and $\alpha 3$ domains. Variable amino acid positions are indicated in blue circles for each domain (codons). The consensus amino acids are based on the *01:01:01:01 amino acid sequence, and the amino acid exchange for each codingregion allele is given. Probably $\mathrm{G}^{*} 01: 13 \mathrm{~N}$ is not expressed; all domains of the $\mathrm{G}^{*} 01: 05 \mathrm{~N}$ may be expressed. Based on IMGT database version 2.28.0, January 2010. See also [12, 109]

\begin{tabular}{|c|c|c|c|c|}
\hline DOMAIN & CODON & $\begin{array}{l}\text { CONSENSUS } \\
\text { AMINOACID }\end{array}$ & CODING-REGION ALLELE & AMINO ACID EXCHANGE \\
\hline & 13 & Ser & G*01:07 & Phe \\
\hline & 27 & Tyr & $G^{*} 01: 12$ & His \\
\hline & 31 & Thr & $\begin{array}{l}\mathrm{G}^{*} 01: 03 \\
\mathrm{G}^{*} 01: 10 \text { and } \mathrm{G}^{*} 01: 11\end{array}$ & $\begin{array}{l}\text { Ser } \\
\text { Met }\end{array}$ \\
\hline & 54 & GIn & $\begin{array}{l}G^{*} 01: 02 \\
G^{*} 01: 13 \mathrm{~N}\end{array}$ & $\begin{array}{l}\text { Arg } \\
\text { Stop-codon }\end{array}$ \\
\hline & 100 & Gly & $\mathrm{G}^{* 01: 14}$ & Asp \\
\hline & 104 & Gly & G*01:15 & Val \\
\hline & 105 & Ser & $G^{*} 01: 16$ & Cys \\
\hline & 110 & Leu & $G^{*} 01: 04$ allelic group, $G^{*} 01: 07, G^{*} 01: 11$ and $G^{*} 01: 15$ & Ile \\
\hline & 130 & Leu & G*01:05N & Reading frame change \\
\hline & 159 & Tyr & G*01:09 & His \\
\hline & 189 & Val & $\mathrm{G}^{*} 01: 05 \mathrm{~N}$ & Stop-Codon \\
\hline & 219 & Arg & $\begin{array}{l}G^{*} 01: 08 \\
G^{*} 01: 14\end{array}$ & $\begin{array}{l}\text { Trp } \\
\text { Gln }\end{array}$ \\
\hline & 258 & Thr & $G^{*} 01: 06, G^{*} 01: 14$ and $G^{*} 01: 16$ & Met \\
\hline & & & & \\
\hline
\end{tabular}


( $\alpha 1$ domain), 3 ( $\alpha 2$ domain) and 4 ( $\alpha 3$ domain), as well as in introns, contrasting with classical HLA class I genes, in which nucleotide variation is clustered around the peptidebinding groove encoded by exon 2 ( $\alpha 1$ domain) and exon 3 ( $\alpha 2$ domain), which influences peptide loading, peptide diversity and $\mathrm{T}$ cell recognition.

Although both classical and non-classical HLA molecules bind to peptides, HLA-G has a limited peptide repertoire. Peptides isolated from placental cells revealed that $15 \%$ of the HLA-G-bound peptides were derived from a single cytokine-related protein [3], and peptides obtained from transfected cells were derived from a restricted number of proteins, including histone $\mathrm{H} 2 \mathrm{~A}$, nuclear and ribosomal proteins, and cytokine receptors $[4,5]$. The conformation of the HLA-G and bound peptide complex is similar to that observed for classical molecules; however, the peptide is buried deeper in the HLA-G cleft (reviewed by Clements et al. [6]). Given these features of the HLA-G peptide ensemble, and considering the absence of reported HLA-G restricted T cells, peptide presentation is not the major function of the HLA-G molecule. Apparently, polymorphic sites around the peptide groove may not influence this biological feature; however, the molecular structure of the distinct HLA-G proteins coupled with different peptides has not been fully investigated.

Membrane-bound and soluble isoforms

HLA-G presents 7 protein isoforms (Fig. 3), generated by alternative splicing of the primary transcript, 4 of them being membrane-bound (HLA-G1, G2, G3 and G4) and 3 soluble (G5, G6 and G7) isoforms. HLA-G1 is the complete isoform exhibiting a structure similar to that of the membrane-bound classical HLA molecule, associated with $\beta 2$-microglobulin. The HLA-G2 isoform has no $\alpha 2$ domain, encoded by exon 3. HLA-G3 presents no $\alpha 2$ and $\alpha 3$
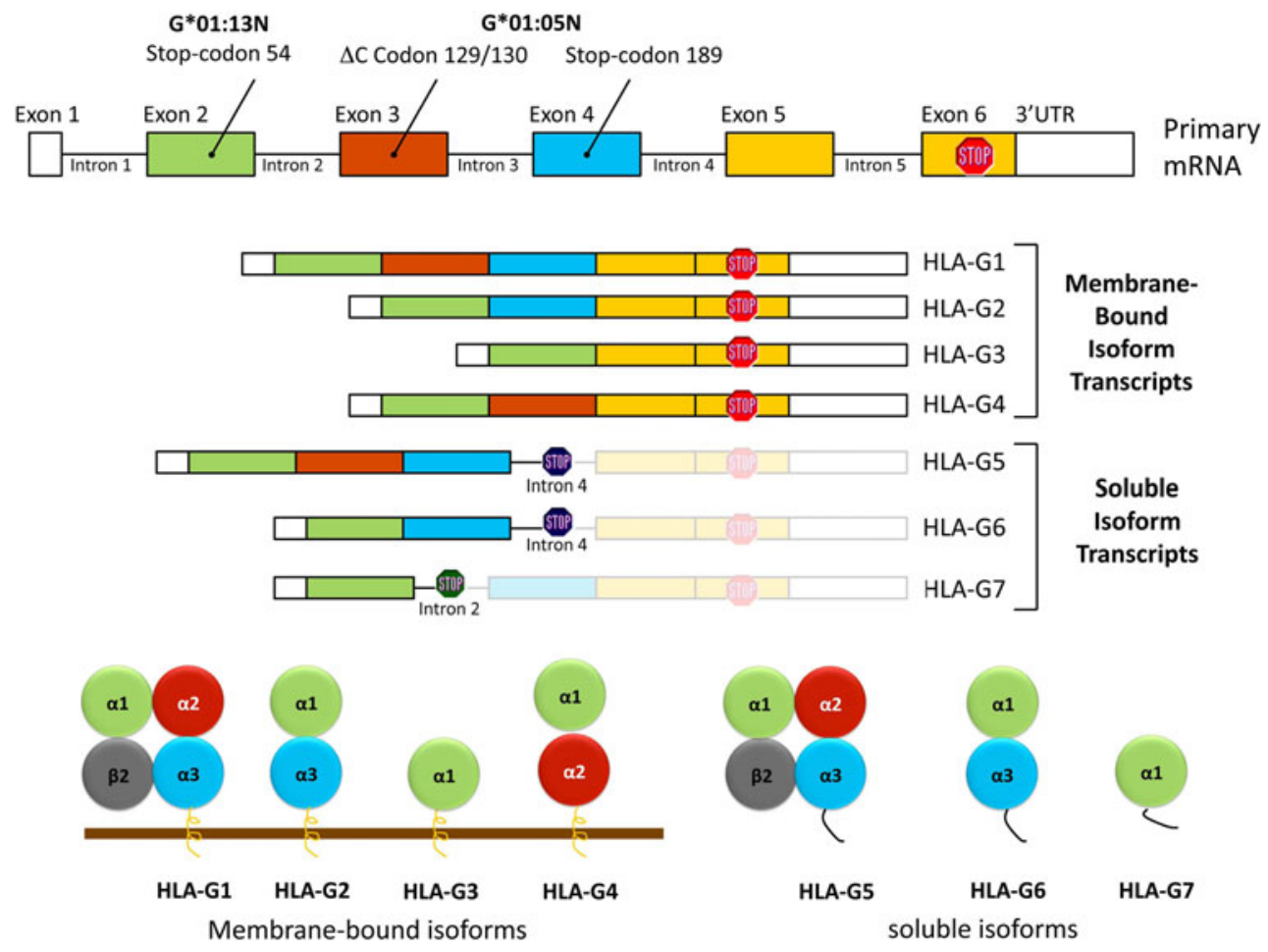

Fig. 3 Isoforms of HLA-G produced by alternative splicing of the primary mRNA. The HLA-G heavy chain domains $(\alpha 1, \alpha 2, \alpha 3$, transmembrane portion and cytoplasmic tail) are encoded by the $H L A-G$ gene (chromosome 6), and the light $\beta 2$-microglobulin molecule is encoded by a gene at chromosome 15. Exon 7 is always spliced out. The final portion of exon 6 and exon 8 is always transcribed, however, never translated due to the presence of a premature stop codon at the beginning of exon 6 (red stop signal), and has been considered as the $3^{\prime}$ untranslated region of the gene $\left(3^{\prime} \mathrm{UTR}\right)$. The primary transcript may be spliced out into 7 isoforms, HLA-G1 to -G7. HLA-G1 is the full-length HLA-G molecule, HLA-G2 lacks exon 3, HLA-G3 lacks exons 3 and 4, and HLA-G4 lacks exon 4. HLA-G1 to -G4 are membrane-bound molecules due to the presence of the transmembrane and cytoplasmic tail encoded by exons 5 and 6 . HLA-G5 is similar to HLA-G1 but retains intron 4, HLA-G6 lacks exon 3 but retains intron 4, and HLA-G7 lacks exon 3 but retains intron 2. HLA-G5 and -G6 are soluble forms due to the presence of intron 4 , which contains a premature stop codon at exon 4 (blue stop signal), preventing the translation of the transmembrane and cytoplasmic tail. HLA-G7 is soluble due to the presence of intron 2 , which presents a premature stop codon (green stop signal). The $\mathrm{G}^{*} 01: 13 \mathrm{~N}$ allele is probably not expressed due to the presence of a premature stop codon at exon 2 (codon 54). A deletion of a cytosine $(\Delta \mathrm{C})$ at exon 3 of the $\mathrm{G}^{*} 01: 05 \mathrm{~N}$ allele changes the reading frame, leading to a stop codon at exon 4 
domains, encoded by exons 3 and 4. HLA-G4 has no $\alpha 3$ domain, encoded by exon 4 . The soluble HLA-G5 and HLA-G6 isoforms present the same extraglobular domains of HLA-G1 and HLA-G2, respectively, generated by transcripts conserving intron 4 , which blocks the translation of the transmembrane domain (exon 5). The $5^{\prime}$ region of intron 4 is translated until the generation of a stop codon, conferring to the HLA-G5 and HLA-G6 isoforms a tail of 21 amino acids implicated on their solubility. The HLA-G7 isoform has only the $\alpha 1$ domain linked to two amino acids encoded by intron 2 , which is retained in the corresponding transcript. All alternative transcripts lack exon 7 [7-10].

Most of the currently described $H L A-G$ alleles may theoretically produce, by alternative splicing, all membrane bound and soluble isoforms. In contrast, the $H L A-G^{*} 01: 05 \mathrm{~N}$ (null allele, $G^{*} 0105 \mathrm{~N}$ ) presents a cytosine deletion $(\Delta \mathrm{C})$ in the last nucleotide of codon 129 or first nucleotide of codon 130 in exon 3 , causing a shift in the reading frame [11, 12], leading to a downstream stop signal (TGA) in codon 189 (exon 4). As a corollary, this allele is associated with an incomplete formation of the HLA-G1, -G4 and G5 isoforms that possess the $\alpha 3$ domain, and normal expression of HLA-G2, G3 and G7 isoforms that lack the $\alpha 3$ domain [12]. The other null allele, $G^{*} 01: 13 \mathrm{~N}\left(G^{*} 0103 \mathrm{~N}\right)$, presents a $\mathrm{C} \rightarrow \mathrm{T}$ transition at the first base of codon 54 in exon $2(\alpha 1$ domain), yielding the formation of a premature stop codon (TAG), which prevents the production of all membranebound and soluble isoforms or produces presumably nonfunctional proteins [13]. Figure 3 illustrates the major features of HLA-G isoforms and major sites responsible for physiological or truncated transcription patterns.

\section{Polymerization}

The presence of a cysteine residue at position 42 in the $\alpha 1$ domain of the heavy chain is a unique feature of the HLA-G molecule, which permits the formation of dimers via a Cyst $42-$ Cyst 42 intermolecular disulfide bond. Dimers may be formed by recombinant HLA-G monomers, membranebound and soluble molecules in transfected cells [14], membrane-bound on the surface of cells that endogenously express HLA-G, and even by $\beta 2$-microglobulin-free HLA-G constructs [15]. Once formed, the dimer has an oblique orientation, exposing the binding sites for CD8 and leukocyte immunoglobulin-like receptors B1/B2 (LILRB1/ LILRB2, also known as LIR1/LIR2, ILT2/ILT4, and CD85j/ CD85d), permitting one HLA-G dimer to interact with two LILR or CD8 molecules. Besides providing higher affinity for LILRs in relation to monomers, HLA-G dimers exhibit enhanced LILR-mediated intracellular signaling [16].

None of the $H L A-G$ alleles already described presents nucleotide variation at codon 42 (TGT) that encodes the cysteine residue. Therefore, apparently all alleles that encode non-truncated HLA-G molecules may form dimers. Since the dimer interface may be stabilized by electrostatic and hydrogen-bond interactions, it is possible that nearby polymorphic residues may influence dimer stability or alter the flexibility of the Cyst42-Cyst42 disulfide bond.

\section{Modulation of the immune response}

Several lines of evidence have supported the role of HLA-G as a tolerogenic molecule, playing an important role in the suppression of the immune response [2, 17]. Overall, all segments of the molecule may contribute to this ability. The short cytoplasmic tail retains HLA-G longer in the endoplasmic reticulum and prolongs the half-life of the molecule on the cell surface because of the lack of an endocytosis motif $[18,19]$, permitting multiple interactions with cells of the immune system. The extracellular domains interact with leukocyte receptors, including CD8, LILRB1 and LILRB2 and the killer cell immunoglobulin-like receptor KIR2DL4 (CD158d) [20, 21].

According to the nomenclature, KIR genes may encode molecules exhibiting two (KIR2D) or three (KIR3D) extracellular immunoglobulin-like domains, which may contain immunoreceptor tyrosine-based inhibitory receptor-ITIM (L-originally for long tail) or not (S-originally for short tail) in the cytoplasmic domain. KIR genes with the "L" designation are predicted to be inhibitory receptors, while those with "S" are predicted to encode activator receptors. Besides, "S" genes contain in their transmembrane domain a positively charged arginine or lysine residue. The KIR2DL4 gene is an exception, containing an arginine in the transmembrane domain and a single ITIM in the cytoplasmic domain. An array of activating and inhibitor receptors is expressed on the surface of most NK cells and macrophages, and the final effector function depends on the balance between activator and inhibitor receptors [22]. Because of these features, the role of the interaction of KIR2DL4 with HLA-G in the modulation of the immune response has been a matter of much debate $[23,24]$. It has even been reported that cross-linking of KIR2DL4 with a specific antibody or the incubation with transfectants expressing HLA-G dimers upregulates several pro-inflammatory cytokines [25]. Overall, the $\alpha 1$ domain of HLA class I molecules is an important KIR recognition site; however, the binding site of KIR2DL4 to HLA-G remains unknown.

Since the Met76 and Gln79 residues are unique to HLA-G, and since the mutation of these residues to Ala76/ 79 affects the binding affinity between KIR2DL4 and HLA-G, these residues may be relevant candidates for this interaction [26]. Although Met76 and Gln79 residues are conserved in the $\alpha 1$ domain of all currently described $H L A-G$ variants, one KIR2DL4 allele (KIR2DL4*006) has 
been associated with susceptibility to preeclampsia [27], suggesting that both HLA-G and KIR polymorphisms may be considered for functional studies.

LILRB1s are expressed on the surface of several leukocytes, such as NK and lymphomononuclear cells, while LILRB2s are primarily expressed on the surface of a restricted set of cells, including monocytes and dendritic cells [28]. Both LILRB1 and LILRB2 have several ITIM receptors in their cytoplasmic tail, inhibiting signaling events triggered by stimulatory receptors [29]. Both receptors interact with classical HLA class I molecules; however, the binding with HLA-G presents three- to fourfold higher affinity when compared to classical molecules [30]. LILRB 1 and LILRB2 bind to the $\alpha 3$ domain and $\beta 2$-microglobulin of the HLA-G molecule; however, LILRB2 binds with higher affinity than LILRB1. LILRB2 binds more to the $\alpha 3$ domain than to the $\beta 2$-microglobulin domain, and the binding sites of these receptors are distinct. The Tyr36 and Arg38 residues of LILRB2 bind to the 195-197 loop of the $\alpha 3$ domain of HLA-G, whereas the Tyr38 and Tyr76 residues of LILRB1 bind to the Phe195 of HLA-G [20]. Given that LILRBs are considered to be the major HLA-G receptors, and since at least 4 $H L A-G$ alleles $\left(G^{*} 01: 06, G^{*} 01: 08, G^{*} 01: 14\right.$ and $G^{*} 01: 16$, see Fig. 2) present non-synonymous polymorphic sites at exon 4 , which codes the $\alpha 3$ domain of the molecule, one might expect that polymorphic residues observed in this domain may influence LILRB interactions, modulating the inhibitory intracellular signaling. It is interesting to observe that the $G^{*} 01: 06$ allele has been associated with preeclampsia in French [31] and Singaporean populations [32].

The CD8 molecule also interacts with the $\alpha 3$ domain of classical and non-classical molecules, including HLA-G and HLA-E, although exhibiting different affinities. CD8 $\alpha /$ $\alpha$ binds to HLA-G with an affinity comparable to that of the $H L A-A * 02$ interaction, contrasting with lower affinity for HLA-E. The affinity of this interaction may vary according to the considered allele. While most $H L A-A$ alleles have high affinity for the $\alpha 3$ domain, $H L A-A^{*} 68: 01$ and $B^{*} 48: 01$ exhibit low affinity. Mutation analyses of classical HLA molecules have indicated that polymorphism at position 245 is responsible for this reduced affinity. The major differences between HLA-E and HLA-G in the $\alpha 3$ domain reside at positions 219, 223 and 224 for HLA-E and 214 and 228 for HLA-G, which are located very close to the HLA/CD $8 \alpha / \alpha$ interaction; i.e., the 223-229 loop of the $\alpha 3$ domain [21]. Although affinity studies have not been performed for variants of HLA-G molecules, those exhibiting different residues in the $\alpha 3$ domain (see Fig. 2) may potentially present diverse receptor affinity. It is interesting to observe that the $\alpha 3$ domain of HLA-G is the same site of interaction with $\mathrm{CD} 8 \alpha / \alpha$ and LILRBs. Although $\mathrm{CD} 8 \alpha / \alpha$ and LILIRB binding sites overlap, LILIRBs inhibit the binding of $\mathrm{CD} 8 \alpha / \alpha$ to HLA molecules, indicating that the inhibitory function of LILRBs may be dual, displacing CD8 $\alpha / \alpha$ and activating ITIMs [30].

Besides the inhibitory role of HLA-G in cytotoxic cells exhibiting CD8 on their surface, other interactions of HLA$\mathrm{G}$ molecules with CD8 cells deserve attention. Soluble HLA-A-B-C and -G molecules can induce apoptosis in $\mathrm{CD}^{+}$activated $\mathrm{T}$ lymphocytes as well as in $\mathrm{CD} 8^{+} \mathrm{NK}$ cells (lacking the $\mathrm{T}$ cell receptor) at similar rates. The binding of soluble HLA molecules to CD8 leads to apoptosis upregulating Fas production and Fas/FasL interaction $[33,34]$. Classical and non-classical soluble molecules may produce similar effects on apoptosis of $\mathrm{CD}^{+}$cells; however, in conditions in which soluble HLA-G is elevated, including pregnancy, some tumors and allografts with good prognosis, this mechanism may represent an additional immunomodulatory effect of HLA-G. Although the precise mechanism of this interaction has not been elucidated, the interaction of soluble forms of HLA-G containing the $\alpha 3$ domain seems to be plausible.

$H L A-G$ non-coding region polymorphism: impact on HLA-G expression regulation

The functional mRNA level of a particular gene is regulated by the rate of synthesis, mainly driven by the promoter region $\left(5^{\prime} \mathrm{UTR}\right)$ of a given gene, as well as by the rate of degradation, stability, localization and translatability of the specific mRNA [35]. Depending on the presence of microenvironmental factors that may upregulate the expression of HLA-G and depending on the genetic background of the individual, theoretically, any tissue might express HLA-G. Furthermore, HLA-G expression may be profitable or harmful, depending on the fine adjustment of the immune response. Pathological conditions in which a vigorous and maintained immune response is desirable, the expression of HLA-G is detrimental, like in chronic viral disorders and cancer. In contrast, when a vigorous immune response is undesirable, the expression of HLA-G is profitable, like in autoimmune disorders and engraftment of allogeneic organs or tissues.

Many factors have been described that potentially affect transcriptional and post-transcriptional mechanisms responsible for HLA-G regulation [36]; however, the reasons for HLA-G expression in some but not in other tissues have not been fully elucidated. In this respect, the promoter and $3^{\prime}$ untranslated regions exhibit numerous nucleotide variations that may influence HLA-G expression and consequently tissue distribution in healthy (placenta, thymus, cornea, pancreas, proximal nail matrix, erythroblasts, mesenchymal stem cells) and pathological conditions (cancer, autoimmunity, transplantation). Besides, variation 
sites observed at introns 1-5 may be involved in HLA-G regulation processes, such as alternative splicing.

\section{$H L A-G$ promoter region polymorphisms}

Overall, classical HLA-class I genes contain two main regulatory modules in the proximal promoter region (200 base pairs upstream of ATG), namely enhancer A (enhA)/ interferon-stimulated response element (ISRE) and SXY [37] (Fig. 4, upper panel). EnhA comprises two palindromic binding sites, $\operatorname{kappa}(\kappa) \mathrm{B} 2$ and $\kappa \mathrm{B} 1$, for the $\mathrm{NF} \kappa \mathrm{B} /$ rel family members [38], and ISRE, a target site for the interferon regulatory factor family, including the interferon regulatory factor-1 (IRF-1) [39]. SXY comprises the X1, $\mathrm{X} 2$ ( site $\alpha$ ) boxes and Y box (also named enhancer B), bound by the multiprotein complex regulatory factor $\mathrm{X}$ (RFX) [comprising RFX5, RFX-associated protein (RFXAP) and RFX-ankyrin(ANK)/B] [40-43], X2 boxbinding protein (X2-BP)/cAMP response element-binding (CREB) [44] and nuclear factor Y (NF-Y) [45]. All these factors cooperate to allow the formation of a stable multiprotein complex and the binding of the class II transactivator (CIITA), which mediates constitutive and IFN- $\gamma$-induced expression of HLA-class I molecules
$[46,47]$. S box function is not fully understood and could possibly play a role in the promoter architecture [48]

The HLA-G promoter region is unique among the HLA genes with a divergent proximal region when compared to the other HLA genes [49]. A modified enhA and a deleted ISRE render the proximal $H L A-G$ gene promoter unresponsive to $\mathrm{NF}-\kappa \mathrm{B}$ [38] and IFN- $\gamma$ [39]. The upstream region encompassing the $\mathrm{SXY}$ module only contains conserved $\mathrm{S}$ and $\mathrm{X} 1$ sequences. While the $\mathrm{X} 1$ box was shown to be a potential target for the RFX5 factors by electrophoretic mobility shift assay [50], chromatin immunoprecipitation assay analysis demonstrated that RFX5 is not associated with the HLA-G promoter in situ [51].

A few alternative regulatory elements within the HLA-G gene promoter have been described. Using HLA-G transgenic mice, a 244-bp positive regulatory region located $-1.2 \mathrm{~kb}$ from the ATG initiation codon of the $H L A-G$ gene is critical for its spatio-temporal expression, presenting a function similar to that of the locus control region (LCR) [52, 53]. The CREB1 factor binds to this region (-1380/-1370), as well as to two additional cAMP response elements (CRE) dispersed through the promoter region at positions -934 and -770 from the ATG,
Fig. 4 Upper panel

Comparison of cis-regulatory elements of classical HLA-class I and $H L A-G$ proximal promoter regions (200 base pairs upstream of ATG). Dotted boxes with slashes indicate mutated regulatory elements in the $H L A-G$ promoter. Mutations prevent binding of major classical HLA-class I transacting factors. RFX complex binds to the conserved $H L A-G \mathrm{X} 1$ box in electrophoretic mobility shift assay but is not associated to the HLA-G promoter in situ. Lower panel Single nucleotide polymorphisms along the whole $H L A-G$ gene promoter sequence (1.4 kb upstream of ATG) as well as the location of the known regulatory elements
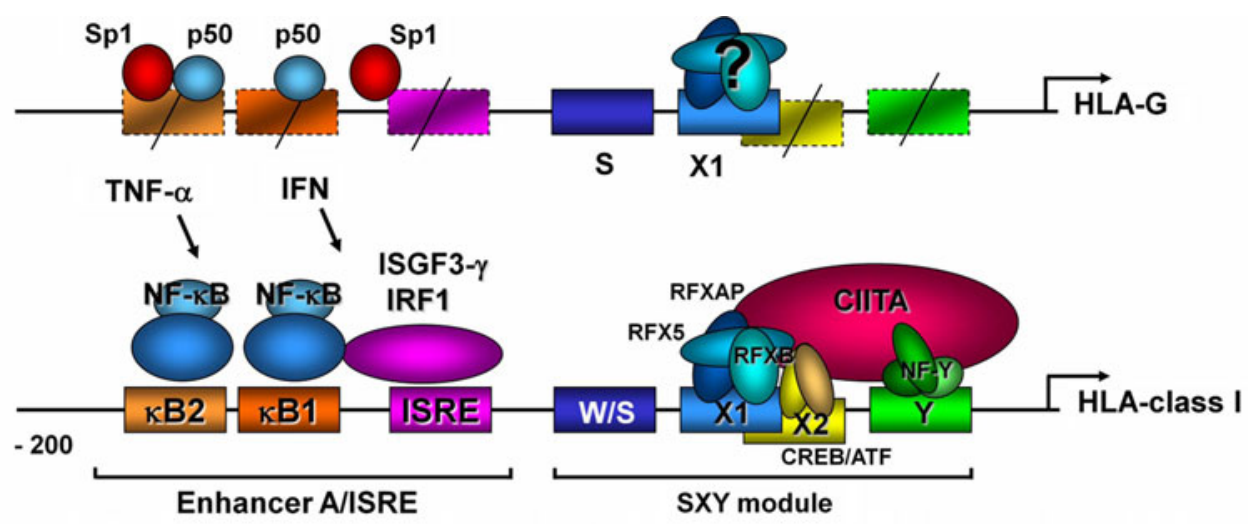

SXY module

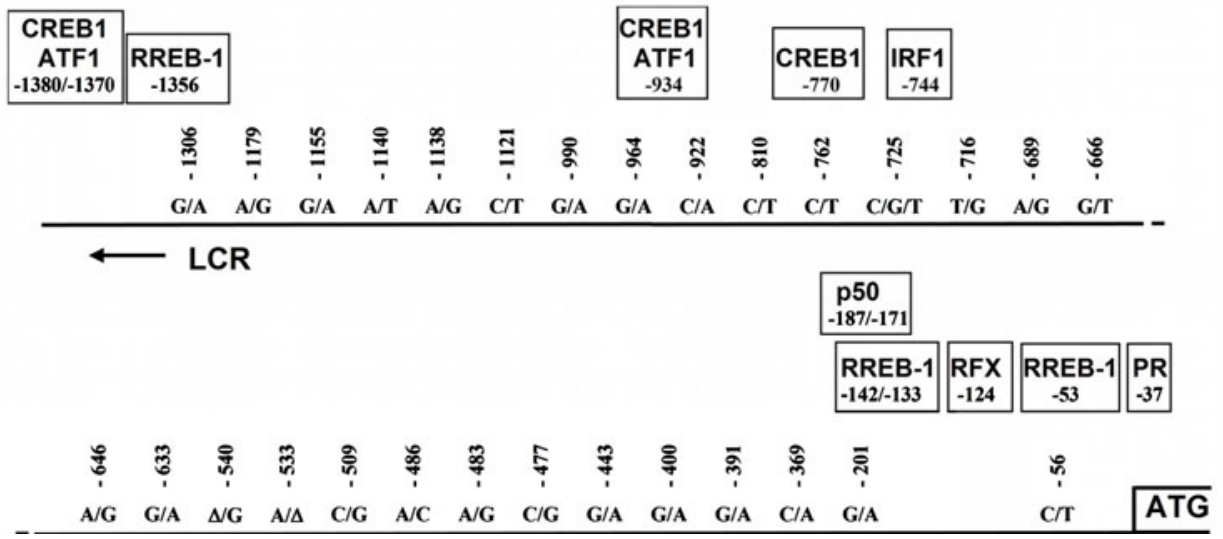


allowing promoter transactivation with the co-activators CREB binding protein (CBP)/P300 [54]. In addition, an ISRE motif, which is highly homologous to the consensus ISRE, is located at position $-744 \mathrm{bp}$ upstream of ATG [55], beside a nonfunctional GAS-like element (-734) [56]. ISRE is a binding site for IFN-response factor-1 (IRF1) and transactivates HLA-G expression following IFN- $\beta$ treatment [55]. A heat shock element (HSE) is located within the $H L A-G$ promoter at position $-459 /-454$ that binds heat shock factor 1 (HSF-1) [57]. Librach's group identified a binding site for the progesterone receptor located $-37 \mathrm{bp}$ from ATG that is overlapping the HLA$G$ TATA box [58]. Finally, the ras responsive element binding 1 factor (RREB-1) was recently demonstrated to downregulate HLA-G transcriptional activity through three ras response elements (RREs) along the $H L A-G$ gene promoter $(-1356,-142,-53)$ [59]. RREB-1 is likely to act through the recruitment of $\mathrm{C}$-terminal binding protein (CtBP) implicated on chromatin remodeling [60].

Contrary to expectations, the $H L A-G$ promoter exhibits numerous variations since 29 SNPs have been identified to date [61-63]. They may be of importance in the regulation of HLA-G expression and may act in different ways. Interestingly, many of these polymorphisms either coincide with or are closed to the known regulatory elements described above, and thus may affect the binding of the corresponding regulatory factors (Fig. 4, lower panel). Based on this assumption, polymorphisms have been identified in the LCR. Regarding $-725 \mathrm{G} / \mathrm{C} / \mathrm{T}$ SNP, the three haplotypes were cloned into luciferase expression vectors and transfected into JEG-3 cells, resulting in a significantly higher expression level of the promoter haplotype containing the $-725 \mathrm{G}$ allele compared with those containing the $-725 \mathrm{C}$ or $-725 \mathrm{~T}$ alleles [64]. Of note is that the $-725 \mathrm{G} / \mathrm{C} / \mathrm{T}$ SNP is very close to ISRE. Along this line, polymorphism in the proximal promoter of Paan-AG, the functional homologue of $H L A-G$ in the olive baboon, was shown to influence $\mathrm{NF}-\kappa \mathrm{B}$ binding and transcriptional activity [65]. In addition, evidence has been accumulated showing that the methylation status of the $H L A-G$ gene promoter is crucial to the transcriptional activity of the gene $[66,67]$. One may speculate that promoter methylation might also be affected by polymorphisms located at CpG sites [64]. Finally, in some cases, polymorphism in the promoter region may be in linkage disequilibrium with 3' UTR variants [68], and some of them could influence alternative splicing [69] and mRNA stability [70].

Interestingly, the pattern of variations observed in the $H L A-G$ promoter region is characterized by two divergent lineages, which is consistent with balancing selection. Ober's group proposed that it was probably related to highly regulated expression favoring high- and lowexpressing promoters under temporally and/or spatially varying selective pressures [61]. Therefore, this should be considered as a very pertinent parameter in the understanding of $H L A-G$ gene regulation and more particularly in some HLA-G-associated diseases. So far, only a few studies have addressed these issues. One study performed in Chicago families and in a Dutch population demonstrated that the GG genotype in SNP -964 G/A was associated with asthma in children of affected mothers, whereas the AA genotype was associated with asthma in children of unaffected mothers [68]. Another study associated the $-725 \mathrm{G}$ variant with sporadic miscarriage [71], but, contrary to expectation, this variant was found to be associated with increased $H L A-G$ transcription [71]. Other studies did not reveal any significant association with $H L A-$ $G$ promoter polymorphism, levels of HLA-G and diseases. No association was observed between $-56 \mathrm{C} / \mathrm{T}$ polymorphism and preeclampsia $(n=118)$ and eclampsia $(n=46)$ [72], or between $-725 \mathrm{C} / \mathrm{G} / \mathrm{T}$ polymorphism with susceptibility to multiple sclerosis (MS) and the course of MS $(n=698)$ [73]. Therefore, additional and larger studies encompassing several polymorphisms of the HLA-G promoter region in various diseases are required for a definitive conclusion. Further functional analysis may complete this scenario.

\section{$H L A-G 3^{\prime}$ untranslated region (3'UTR) polymorphisms}

Since exon 7 is always absent from the mature mRNA and, due to the stop codon in exon 6 , exon 8 is not translated, this gene segment has been considered to be the $3^{\prime}$ UTR of the mature RNA. The HLA-G $3^{\prime}$ UTR contains several regulatory elements [35], including polyadenylation signals and AU-rich elements [74], as well as signals that regulate the spatial and temporal expression of an mRNA [35]. The primary transcripts must be processed and bound by proteins before being exported to the cytoplasm [75]. In this process, the Cap protein is added, introns are removed by the spliceosome, and the $3^{\prime}$ ends are cleaved and polyadenylated. The Cap-binding complex (CBC) binds to the $5^{\prime}$ monomethylated cap structures and poly(A)-binding proteins (PAB) to the $3^{\prime}$ tail in order to export competent messenger ribonucleoprotein particles (mRNPs) necessary to mRNA transportation and translation [35, 75]. The proteins that bind to an mRNA can influence its translation, localization and degradation, and any polymorphism at $3^{\prime} \mathrm{UTR}$ of a given gene may influence the binding properties. The availability of the mRNA for translation is constantly balanced by the opposing force of mRNA retention and decay, in which non-functional and deleterious transcripts may be eliminated before translation [35, 75-77] (for a detailed review regarding the $3^{\prime}$ UTR translational control see [35]). In addition, a $3^{\prime} \mathrm{UTR}$ of a given gene may be a target for microRNAs (miRNAs), which are 
small non-coding RNAs with approximately 22 nucleotides processed from longer precursors. miRNAs may negatively regulate gene expression by translation suppression, RNA degradation or both $[35,78]$. The first miRNA was reported in 1993 [79], and more than 600 have been reported to date [80].

Before going to the HLA-G $3^{\prime}$ UTR polymorphisms, it should be mentioned that there is no consensus in the literature regarding the position of the nucleotide variation in this region. As reported by IMGT, the first nucleotide of the coding sequence of the $H L A-G$ gene is the adenine of the first codon at exon 1 (ATG), extending the sequence until position 2838 at intron 6 . Since there is no official information beyond this point, nucleotide positions that we and other authors have used $[78,81,82]$ infer polymorphic sites at $3^{\prime}$ UTR using the original HLA-G sequence described by Geraghty et al. [83], considering the first base the adenine of the first ATG codon at exon 1, as well as public sequences reported for chromosome 6 . On the other hand, other authors have used the original sequence described by Geraghty et al. [83], including part of the promoter sequence, a region encompassing 781 nucleotides before the first ATG. Currently, more than 1,500 nucleotides are considered to be the promoter sequence, and 781 bases represent only an aleatory fragment of the promoter region base sequence, as originally reported in 1987 . Therefore, these authors refer to $3^{\prime}$ UTR polymorphisms encompassing these 781 base pairs. In addition, the original sequence described by Geraghty et al. does not consider the 14 base pair (bp) insertion, since the sequenced allele was G*01:01:01:01, which has a 14-bp deletion. Given that 14bp insertion or deletion allele frequencies are closely similar in several populations, and given that the insertion allele is present in gorillas and chimpanzees, probably representing the ancestor allele, the 14-bp sequence should be included in the sequence, as considered by us and other authors [78, 81, 82]. Therefore, the nucleotide variation sequence considered from the first ATG codon at exon 1, including the 14-bp insertion, seems to be the more appropriate form to assign 3'UTR polymorphisms. For instance, the SNP at the $+3010 \mathrm{C} / \mathrm{G}$ position is considered by other authors as +3777 , i.e., 3010 plus 781 (aleatory part of the promoter region) minus $14 \mathrm{bp}$ (a segment absent in the allele described by Geraghty et al.).

The $H L A-G$ gene exhibits a $3^{\prime} \mathrm{UTR}$ presenting AU-rich motifs, a poly-A signal, and several polymorphic sites that may potentially influence HLA-G transcription, translation or both by several different mechanisms. Among them, it is worth mentioning: (1) the presence (insertion) or absence (deletion) of a 14-bp fragment (INDEL polymorphism), which has been associated with mRNA stability, (2) the SNP at the +3142 position, which may be a target for certain miRNAs, degrading HLA-G mRNA, and (3) the
SNP at the +3187 position, which is related to mRNA stability and degradation. Figure 5 illustrates the $3^{\prime}$ UTR of the $H L A-G$ gene, emphasizing the polymorphic sites that may influence HLA-G expression.

Although the 14-bp INDEL polymorphism has been associated with the magnitude of HLA-G production [84], modulating HLA-G mRNA stability [70, 85-87], the mechanisms implicated have not been elucidated. HLA- $G$ alleles presenting the 14-bp (5'-ATTTGTTCA TGCCT- $3^{\prime}$ ) sequence [88] have been associated with lower mRNA production for most membrane-bound and soluble isoforms in trophoblast samples [87, 89]. On the other hand, a fraction of HLA-G mRNA transcripts presenting the 14-base insertion can be further processed (alternatively spliced) by the removal of 92 bases from the mature HLA-G mRNA (Fig. 4) [85, 87], yielding smaller HLA-G transcripts, reported to be more stable than the complete mRNA forms [70]. The ratio between -92 and +92 base transcripts may vary according to the cell line studied, being 0.5 for JEG-3 cells (that endogenously produces HLA-G) and 0.2 for transfected M8 melanoma cells [70]. This alternative splicing is probably not only driven by the presence of the 14-base fragment in the primary transcript and may be a consequence of the presence of other polymorphisms in linkage disequilibrium with the 14-bp insertion. In fact, JEG-3 cells are homozygous for the $G^{*}$ 01:01:03 allele, and M8 cells are transfected with the $G^{*}$ 01:01:02 allele, both presenting nucleotide differences in exons 3 and 5, and also in introns 1 and 4 . In addition, both $G^{*} 01: 01: 03$ and $G^{*} 01: 01: 02$ alleles are associated with different 3 'UTR haplotypes that differ at the +3035 , +3187 and +3196 positions, all preserved after the alternative splicing $[82,90]$. In conclusion, the combination of such polymorphisms, encompassing the coding region and $3^{\prime}$ UTR, may influence the amount of primary 14-base insertion transcripts that lose the 92-base sequence.

The nucleotide variation at the +3142 position (Fig. 5) was recently explored by Tan et al. [81], who demonstrated that this marker may be related to susceptibility to asthma as well as influencing HLA-G expression. The presence of a guanine at the +3142 position may influence the expression of the $H L A-G$ locus by increasing the affinity of this region for the microRNAS miR-148a, miR-148b and miR-152, therefore decreasing the mRNA availability by mRNA degradation and translation suppression. The influence of the $+3142 \mathrm{G}$ allele was demonstrated by a functional study in which HLA-G high-expressing JEG-3 cells were transfected with miR-148a, decreasing soluble HLA-G levels. In addition, the miRNAs miR-148a and miR-148b were detected in bronchial epithelial cells but were underrepresented in the cytotrophoblast cells, which is in agreement with the higher expression of HLA-G in cytotrophoblast in relation to bronchial epithelial cells. Similarly to miR-142a, 


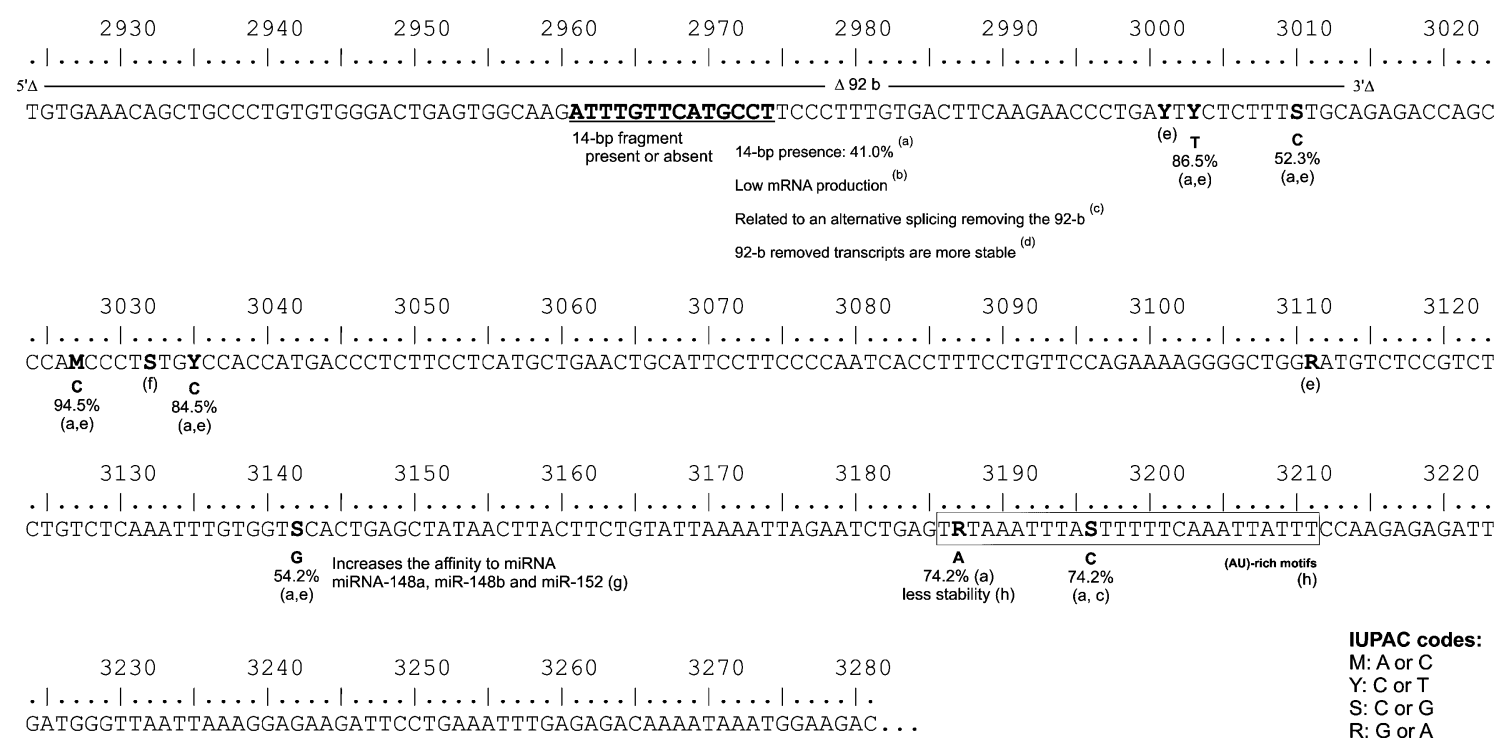

Fig. 5 Variation sites, described by us and by other authors, observed in the $H L A-G 3^{\prime}$ untranslated region, which may influence HLA-G expression. The frequencies of some of these polymorphic sites observed in a highly heterogenous population such as Brazilians are

miR142b and miR-152, an in silico analysis has revealed that several human miRNAs have the potential to bind to the HLA-G mRNA 3'UTR and influence HLA-G expression. The binding ability of these miRNAs may potentially be influenced by several polymorphisms present in the HLA$G 3^{\prime} \mathrm{UTR}$, emphasizing the role of the 14-bp fragment, SNPs at the $+3003,+3010,+3027$ and +3035 positions, which encompass a region of only 32 nucleotides that may influence the binding of several miRNAs, and the +3142 SNP, as previously discussed [90].

A recent study has reported that the presence of an adenine at the +3187 position is associated with preeclampsia in a Canadian population [91]. This SNP is near (4-bp upstream) an AU-rich motif that mediates mRNA degradation. The same report demonstrated that this SNP is associated with decreased RNA stability in vitro, and the presence of the $+3187 \mathrm{~A}$ allele may lead to a decreased HLA-G expression [91].

These three polymorphic sites associated with HLA-G production may also be associated with each other, illustrating a scenario in which their influence may not be mutually exclusive. It is noteworthy that the 14-bp insertion is always accompanied by the $+3142 \mathrm{G}$ and $+3187 \mathrm{~A}$ alleles, both previously associated with low mRNA availability, indicating that the low mRNA production associated with the 14-bp insertion [87] may also be a consequence of the presence of these polymorphisms associated with the 14-bp fragment [82].

In addition to the described variation sites discussed above, the $3^{\prime}$ UTR presents several other polymorphisms frequently observed in highly genetically diverse also shown. a Castelli et al. [82]. b Hviid et al. [87]. c Hiby et al. [85]. d Rousseau et al. [70]. e Alvarez et al. [74]. f Unpublished data. This SNP was found in the Brazilian population in only two individuals. g Tan et al. [81]. h Yie et al. [91]

populations [82, 92], which have not been associated with differential HLA-G expression so far, as illustrated in Fig. 5. The polymorphic sites at the $3^{\prime}$ UTR seem to be arranged in several haplotypes, each of them associated either with a single or a group of coding and promoter region polymorphisms [74, 82], creating an extended $H L A$ $G$ haplotype. Exemplifying, the $+3003 \mathrm{C}$ allele is associated with other $3^{\prime} \mathrm{UTR}$ variation, including the 14-bp deletion, $+3142 \mathrm{C}$ and $+3187 \mathrm{~A}$ alleles, as well as the coding region nucleotide variation typical of the $G^{*}$ 01:01:01:05 allele, and further with a specific promoter region polymorphism [82].

In conclusion, in contrast to the coding region, the $3^{\prime}$ UTR of the HLA-G locus presents a high degree of variation, presenting several polymorphic sites that may potentially influence mRNA stability, turnover, mobility and splicing pattern. The expression of HLA-G is a complex process modulated by many factors such as the promoter efficiency, driven by $5^{\prime}$ promoter polymorphisms, and the rate of mRNA degradation or translation, highly influenced by the mRNA 3'UTR polymorphisms. Although several polymorphisms in the $H L A-G 3^{\prime} \mathrm{UTR}$ have been previously related to mRNA stability or degradation, their influence seems to occur simultaneously since these alleles are characteristically associated in haplotypes.

\section{Evolution aspects of HLA-G}

To understand the mechanisms that generated diversity at the $H L A-G$ locus, some evolutionary aspects observed in 


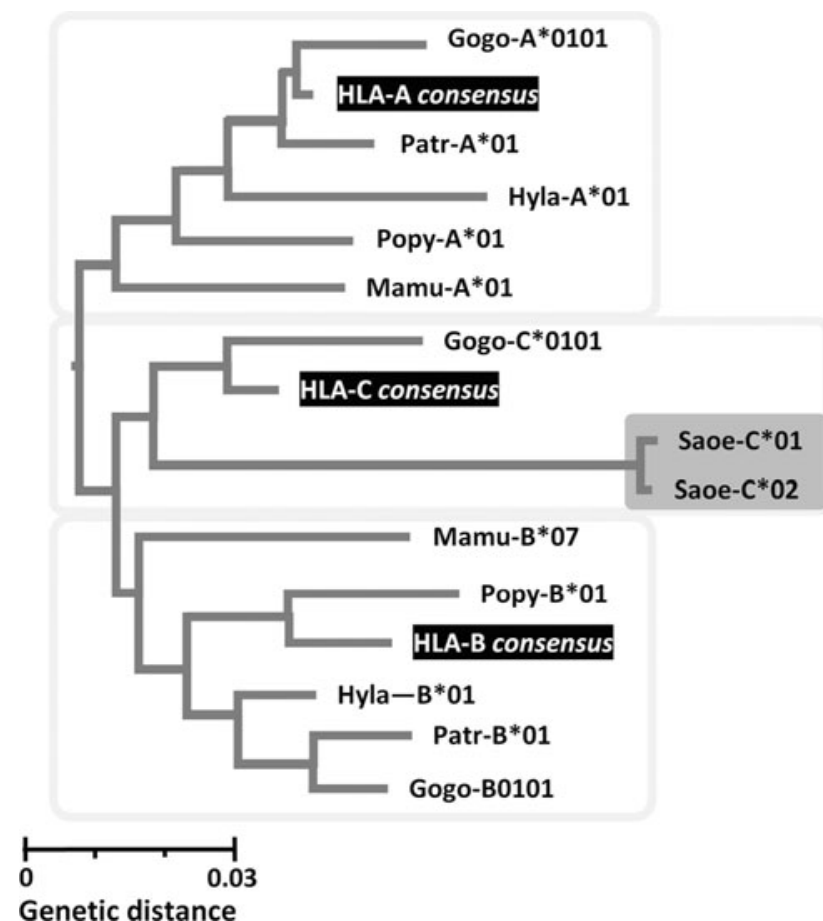

Fig. 6 New World monkeys: the cotton-top tamarin (Saguinus oedipus, Saoe) MHC-C. Two different MHC-C sequences have been found (GenBank accession numbers AF005217 and AF005218), which cluster with other primates MHC-C. This is represented in a NJ dendrogram. HLA human MHC, Patr chimpanzee, Gogo gorilla, Popy orangutan, Hyla gibbon, Mати M. mulatta

New and Old World primates, in Pongidae and in humans are emphasized, including the genetic diversity of the $H L A-G$ locus in worldwide populations.

To avoid misunderstandings regarding the primate Major Histocompatibility Complex nomenclature, the general abbreviation MHC-G will be used to assign the $H L A-G$ homologous locus. A similar approach will be used for other MHC loci.

New World primates

Considering the lineage that gave rise to Old World and anthropoid monkeys, the New World monkey lineage separated about 38 million years ago (mya). The cotton-top tamarin (Saguinus oedipus, Saoe) that inhabits the CentralSouth American continent (Costa Rica, Panama, Colombia) is a typical example of this group. Saoes presumably have functional MHC-G-like genes instead of MHC-A and -B genes [93]. MHC-C sequences have also been detected ([94], Fig. 6), which may strongly interact with KIRs [95]. Saoes share more sequence homologies with HLA-G than with classical HLA class I genes [93, 96]. Thus, it has been proposed that HLA-G could be the ancestral MHC class I gene and that MHC class I genes of the Saoes could be homologous to the $H L A-G$ locus. On the other hand, it has

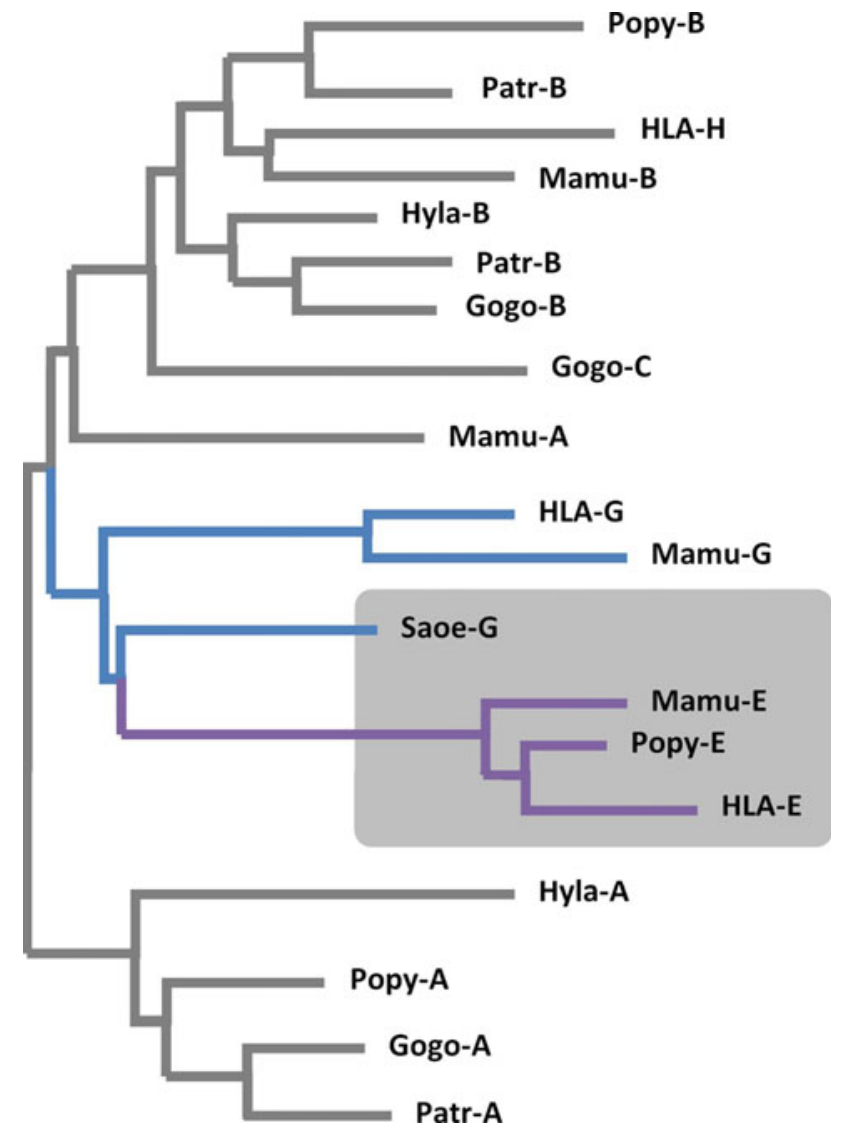

Fig. 7 The MHC-G DNA sequence of cotton-top tamarins (Saoe) is more closely related to the primate MHC-E than to the primate MHC$\mathrm{G}$ sequence in the $\mathrm{NJ}$ tree (shown), also regarding DNA base percentage similarity (not shown). HLA human MHC, Patr chimpanzee MHC, Gogo gorilla MHC, Popy orangutan MHC, Hyla gibbon MHC, Мати M. mulatta

also been shown that MHC-E may be more similar to Saoe MHC (Fig. 7) when MHC-G and, in addition, MHC-E are analyzed together [95, 97].

MHC-G intron 2 sequences show conserved motifs in all primate species studied so far, particularly a 23-bp deletion between positions 161 and 183, which seems to be locus specific [97, 98]; however, the Saoe MHC-G intron 2 does not bear this deletion (Fig. 8), which is surprising. The two most feasible explanations for this phenomenon could be that: (1) the MHC-G-like sequences in Saoe described did not give rise to the Old World monkey and human MHC-G alleles, or (2) the 23-bp deletion (Fig. 8) most likely occurred after separation of the New World:Old World monkey lineages about 38 mya. The first hypothesis is more plausible since eluted peptides from cotton-top tamarin MHC-G like molecules are not typical of MHC-G [G. Rammansee, personal communication, 4]).

On the other hand, Saoe usually gives birth to monozygotic twins after 4-5 months of pregnancy and, thereafter, their fathers take care of the newborns until they 


\begin{tabular}{|c|c|}
\hline$H L A-A^{\circ}$ & $A .0101$ \\
\hline$H L A-B^{\circ}$ & $8 \cdot 5101$ \\
\hline $\mathrm{HLA}-\mathrm{Cn}$ & $\sigma * 1101$ \\
\hline$H L A-J$ & \\
\hline$H L A-F$ & \\
\hline$H L A-E^{\circ}$ & $8 \cdot 0102$ \\
\hline HLA- 6. & 6.0 \\
\hline$H L A-G$ & BeWO \\
\hline Patr $x$ & Nanc $-G * 01$ \\
\hline $\operatorname{cog} 0 x$ & Mhe $-6 * 01$ \\
\hline Popy & Mhe $-G * 01$ \\
\hline Popy & Mac $-6 * 02$ \\
\hline Mafa & Nhe $-G * 04$ \\
\hline Mafa & she $-G \cdot 01 /-G \cdot 02 /-G \cdot 03$ \\
\hline Coas $A$ & Nehe $-G \bullet 01$ \\
\hline Coae $\mathrm{A}$ & Mhe $-G * 02$ \\
\hline Mamu & Manc $-G \bullet 02$ \\
\hline Mamu $A$ & Mhe $-G \cdot 04$ \\
\hline Mamu $A$ & Mhe $-G \bullet 01 /-G \bullet 03$ \\
\hline saoe-c & $-G \cdot 02 / 04$ \\
\hline
\end{tabular}

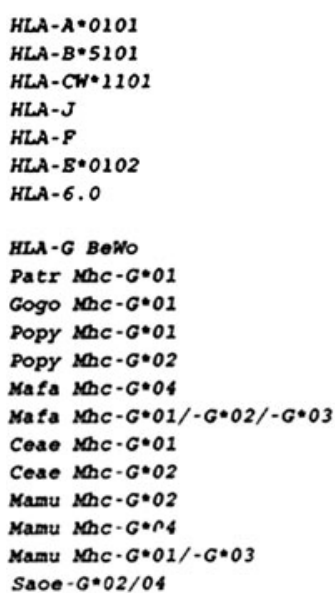
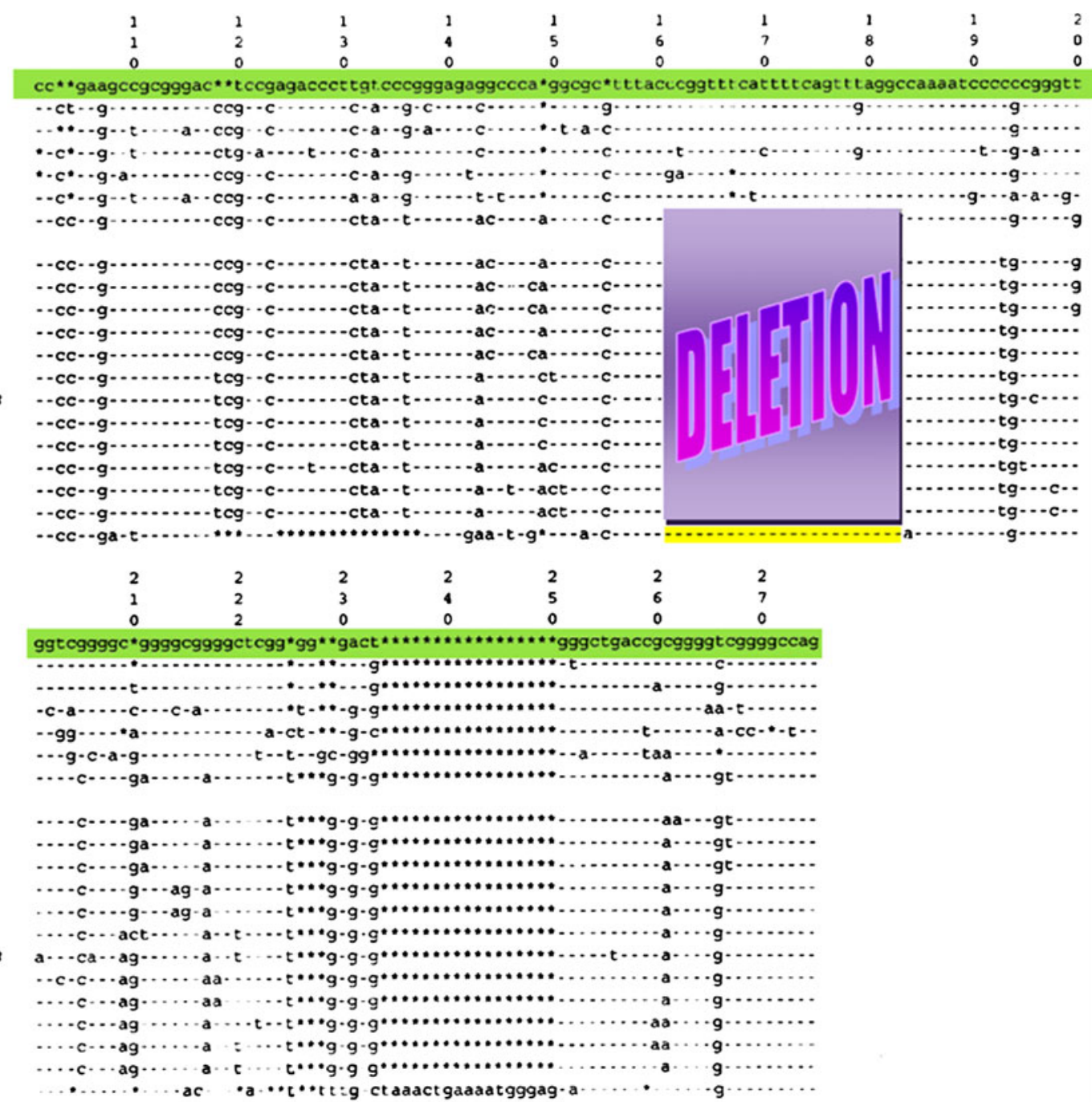

Fig. 8 MHC-G intron 2 nucleotide sequences compared to other MHC sequences (see also [98, 101]. The box indicates the 23-bp deletion observed in all introns 2 from MHC-G sequences. Cotton-top tamarins (Saoe) do not show this typical deletion, and this feature further casts doubts about whether the described cotton-top tamarin's majority MHC alleles belong to the MHC-G lineage. Otherwise, this deletion may have appeared in the Old World monkey's lineage. Saoe intron 2 sequence belongs to Saoe-G*02 and $-G^{*} 04$ alleles, which were sequenced in three different monkeys. Identity between residues is indicated by a dash and deletions are denoted by an asterisk are weaned and only give them to their mother for feeding [99]. Whether or not this peculiar pregnancy is related to the peculiar MHC-G system of this species has to be determined. Due to the high polymorphism observed in Saoe MHC-G molecules (11 alleles) (Fig. 9), it is possible that these G-like molecules are classical antigen-presenting molecules in New World monkeys since no other class I MHC molecules have been found, except one that seems to be MHC-C, not known to be translated into protein [94, 95, 100].

In conclusion, many MHC-G-like molecules exist in monkey species that separated from the human lineage at least 38 mya. Since MHC-G alleles present polymorphic sites at the $\mathrm{T}$ cell receptor, $\mathrm{NK}$ receptor and antigen binding sites, it is likely that the MHC-G function of these
New World monkeys is similar to classical HLA class I presenting molecules.

\section{Old World primates (Cercopithecinae subfamily)}

This group of monkeys lives in Eurasia and Africa. Their pregnancies last 5 months, and they usually deliver just one newborn. The MHC-G alleles of M. mulatta (Mamu, rhesus monkey), M. fascicularis (Mafa, cynomolgous monkey) and $C$. aethiops (Ceae, green monkey) all bear stop codons in a very restricted area of exon 3 (at codon 164), and some alleles may also show stop signals at codons 133, 118 and 176 ([101], (Fig. 10). The $\alpha 1$ domain of the molecule is always preserved in all species studied and may suffice for MHC-G function in Cercopithecinae. Considering the 
Fig. 9 Saoe (cotton-top tamarins) MHC-G clusters in relatedness dendrograms with MHC-E of other primates (see Fig. 7)
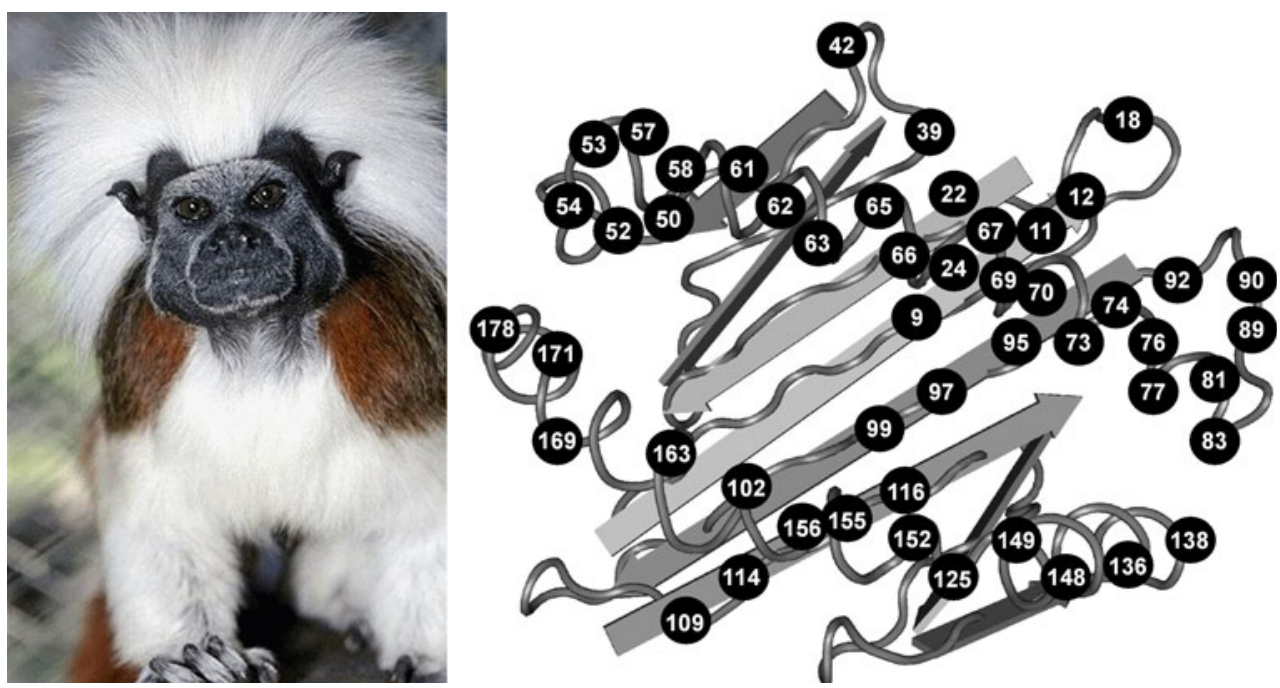
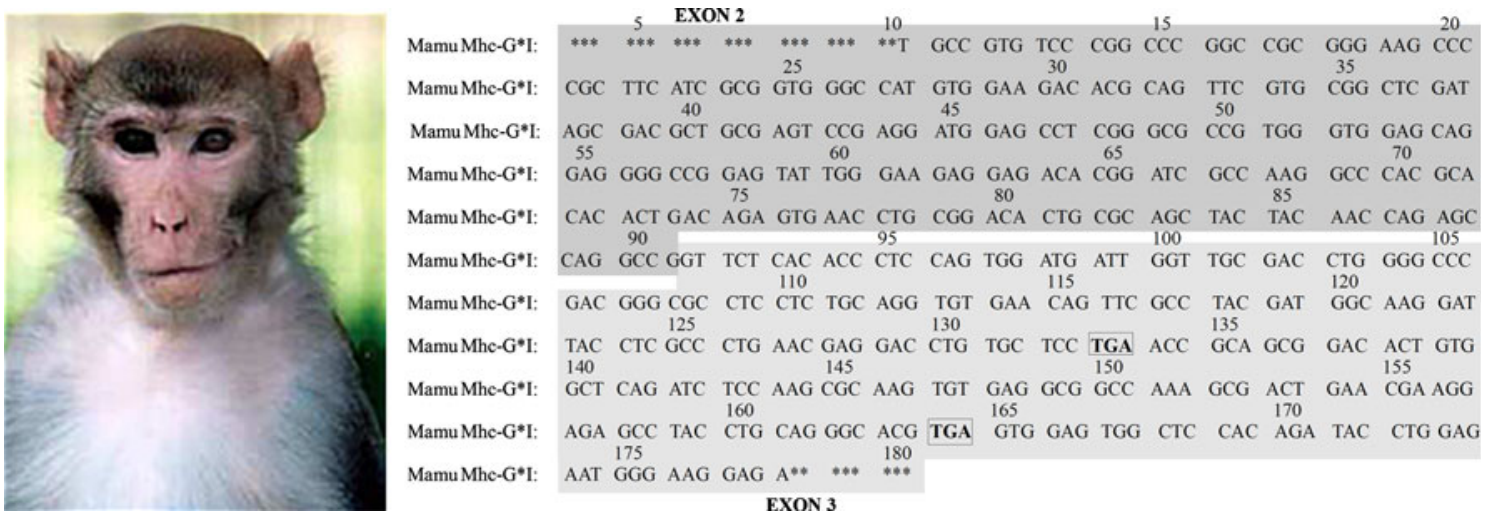

Fig. 10 Macaca mulatta. MHC-G exon 2 and exon 3 sequences, showing two stop codon positions at exon 3 (TGA) (five individuals were studied). Macaca fascicularis (four individuals) and Cercopithecus aethiops (five individuals) also showed stop codons at MHC-G

postulated role of MHC-G in preserving the fetus from maternal NK cell attack, and considering that the pregnancies are normal, usually bearing just one fetus, functional MHC-G molecules may exist in these species lacking the $\alpha 2$ domain. Otherwise, the existence of readingthrough stop codon mechanisms may be present, as found in certain mammalian genes [102-104].

A total of 43 Cercopithecinae individuals were tested for the presence of a stop codon at position 164, and it was observed in all of them. This is a general feature of this subfamily, which may have occurred before speciation within the group precursors (at least 30 mya, when they separated from higher primates, Hylobates and Pongidae). Stop base triplets have also been reported in humans at codon 107, and the presence of a cysteine at codons 101 and 164 , crucial to maintain the overall molecule tertiary structure, has also been found to be substituted by another amino acid [101]. All these variations were observed in a heterozygous form. In these species, mothers are exposed exon 3. All of these monkeys belong to the Cercopithecinae family and show one stop codon at the 164 position. Some other Macaca species (43 individuals were studied) show additional stop codons at 118,133 and 176 exon 3 residues [101]

to relatively few allogeneic fetuses since $92 \%$ of pregnancies have the $\alpha$-male as a father [99].

In conclusion, only postulated isoforms not bearing the $\alpha 2$ MHC-G domain are found in Cercopithecinae monkeys due to the existence of stop codons in homozygosis mainly at position 164, although other stop codon positions are observed. These mutations appeared in the Cercopithecinae common ancestors after the separation from the human and Pongidae lineages about 35 mya. Either $\alpha 2$-lacking MHC-G isoforms may suffice for function or all isoforms may be possibly due to stop codons reading-through mechanisms.

\section{Pongidae}

Gorillas and chimpanzees (Figs. 11a, b) do not seem to have high polymorphism at MHC-G; however, more individuals need to be studied. The almost non-existence of nucleotide variation parallels the relatively low 


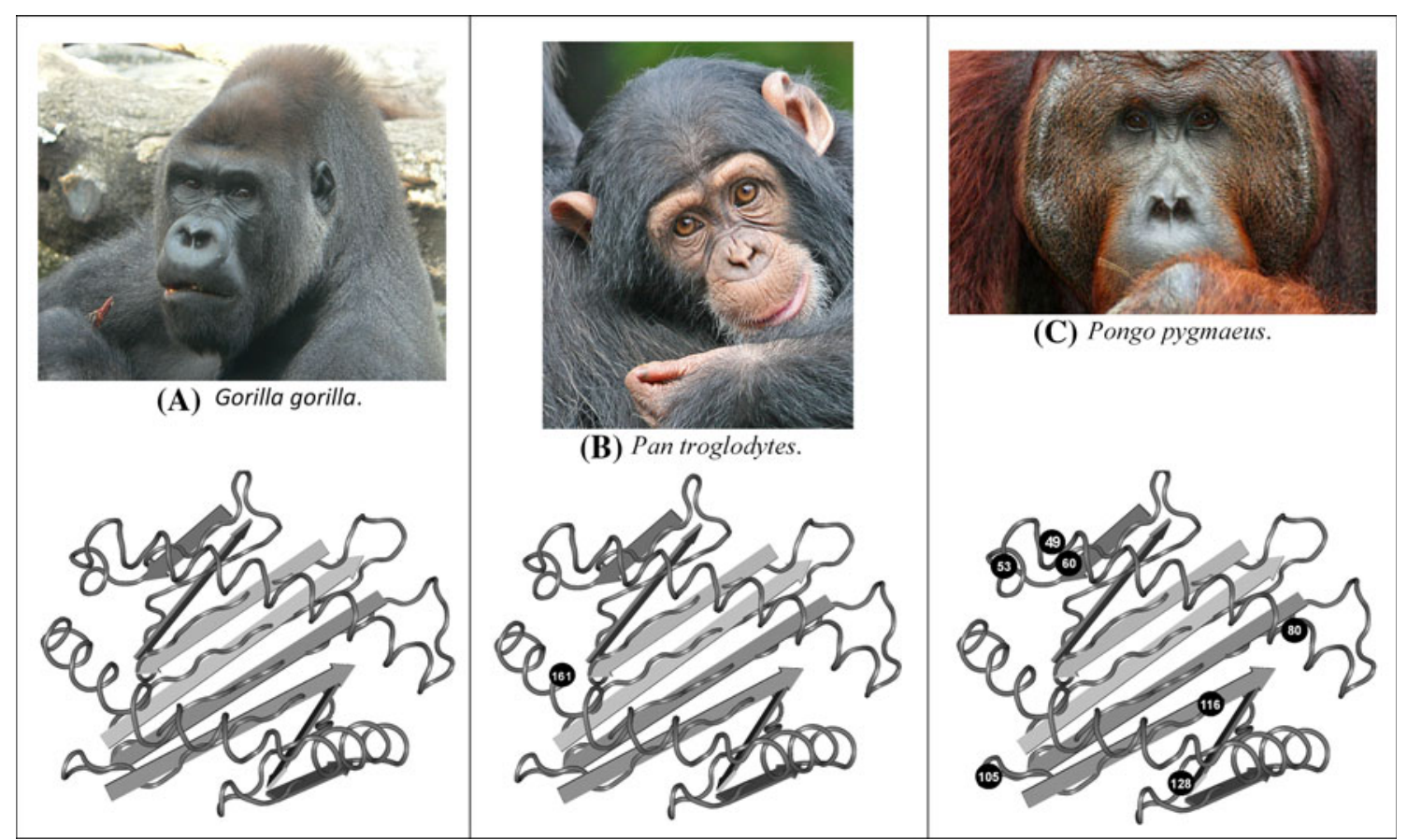

Fig. 11 MHC-G molecule ( $\alpha 1, \alpha 2$ and $\alpha 3$ domains) in primates. a Gorilla gorilla: only one MHC-G allele was found; b Pan troglodytes: one variable position and two different MHC-G alleles were found; and c Pongo pygmaeus: MHC-G alleles found in variable positions in five orangutans. Variable amino acid positions are indicated in circles for each domain cluster (codons) polymorphism seen in humans (see Fig. 2) [98, 105]. Mothers show relatively high exposure to allogeneic fetuses due to polygamy [99]. However, the orangutan (Fig. 11c) shows five encoded proteins that affect both the $\mathrm{T}$ cell receptor and the antigen binding site. Thus, the very low MHC-G polymorphism may only have appeared 15 mya, when the orangutan diverged from the human lineage. Orangutans may show long lasting male-female relationships that expose mothers to relatively few allogeneic fetuses [99].

In conclusion, orangutans that separated from the human lineage about 15 mya show more MHC-G alleles than gorillas and chimpanzees, exhibiting variability at the $\mathrm{T}$ cell receptor, NK and antigen binding sites.

\section{Humans}

Similar to gorilla and chimpanzee, humans also present low coding region polymorphisms, encoding only 14 common proteins. Many Negroid, Caucasoid and Mongoloid individuals have been studied [98, 105] (Table 1), yielding sound results. The allelism apparently does not drastically affect the HLA-G molecule function. According to these data, the coding-region of the HLA-G gene seems to suffer a strong selective pressure for invariance (purifying selection), i.e., preservation of nucleotide and amino acid sequences, reduced variability and lower than expected non-synonymous mutation rate [106]. However, humans bearing the null allele $\left(G^{*} 01: 05 \mathrm{~N}\right)$ in homozygosis have been found [107-109], which may indicate that soluble HLA-G molecule or molecules lacking the $\alpha 3$ domain are sufficient for HLA-G function.

The selective forces acting at the promoter region and $3^{\prime}$ UTR of the $H L A-G$ gene seem to be different from those acting at the coding region. The pattern of variation of the promoter region is characterized by two divergent lineages of haplotypes, which has been maintained by balancing selection in worldwide human populations studied so far. These lineages may have different promoter activity and may modulate the fine balance between high- and lowexpressing $H L A-G$ haplotypes [61]. It is noteworthy that the majority of SNPs described in the promoter region are located in transcriptional factor binding-sites (Fig. 4, lower panel), so heterozygosis in these regions may strongly affect the promoter responsiveness to several transcriptional factors. In addition, the $3^{\prime}$ UTR seems to undergo the same pattern of selective pressure of the promoter region. The two most common 3'UTR haplotypes found in highly genetically diverse populations, such as Brazilians, differ in 5 out of 8 points of variation, including those already described influencing HLA-G expression (14-bp, +3142 and +3187$)$. Given that, and considering that both present frequencies of approximately $25 \%$ [82], one may assume that this region may also suffer balancing selection.

The within-species peculiarities of MHC-G genes in primates (not following a linear evolutionary pattern) 
suggest that behavior peculiarities give rise to particular fetal-maternal relationships that may shape MHC-G evolution. For instance, cotton-top tamarins always give birth to monozygotic twins, which thereafter cling to the father and are born to long-lasting monogamous couples. All other primates are polygamous (polygamy, especially in primitive societies, is a human characteristic), and mothers may be in contact with many different fetuses regarding MHC antigens. However, Cercopithecinae and orangutans (species less exposed to allogeneic fetuses) are the most polymorphic at the MHC level [101]. A hypothesis may be raised that a mechanism avoiding a high MHC-G allelism has been developed in polygamous species (Old World and anthropoid monkeys and humans). This would protect the mother against frequently MHC incompatible trophoblast aggression (as seen in some pregnancy-related tumors) and, on the other hand, would confer to the mother a simple non-polymorphic system to switch off fetal NK and other immune system cells [17].

Since each primate species seems to have undergone a particular evolutionary pathway, further research studies are needed to understand the MHC-G 40 million year evolution, as summarized in this paper.

\section{Population genetics in humans}

As per definition, a polymorphic site must be present in a population at a frequency higher than $1 \%$; however, some $H L A-G$ variation sites may not be considered true polymorphisms, since they are observed in just one or in a few individuals. Among the 13 SNPs described for exon 2, 12 for exon 3 and 8 for exon 4, apparently only four SNPs (one in exon 2, two in exon 3 and one in exon 4) do present frequencies higher than $1 \%$ in worldwide populations [ 31 , $82,89,105,110-116]$. The majority of these SNPs are synonymous substitutions, and only one non-synonymous substitution in each of exons 2,3 or 4 does present a frequency higher than $1 \%$ in worldwide populations $[31,82$, 89, 105, 110-115].

Regarding the consensus allele family $\left(G^{*} 01: 01\right)$, only 4 variation sites in the coding region of the $H L A-G$ locus are related to amino acid exchange, which is frequently found in worldwide populations: (1) the $+292 \mathrm{~A} \rightarrow \mathrm{T}$ SNP at exon 2 (codon 31), exchanging a threonine for serine, characteristic of the $G^{*} 01: 03$ allele; (2) the $+755 \mathrm{C} \rightarrow \mathrm{A}$ SNP at exon 3 (codon 110), exchanging leucine/isoleucine, typical of the $\mathrm{G}^{*} 01: 04$ allele group; (3) the $\Delta \mathrm{C}$ deletion at exon 3, typical of the $\mathrm{G}^{*} 01: 05 \mathrm{~N}$ allele; and (4) the +1799 $\mathrm{C} \rightarrow \mathrm{T}$ SNP (codon 258), exchanging threonine for methionine, characteristic of the $G^{*} 01: 06$ allele. In practical terms, with exception made for the null alleles, only four different HLA-G proteins are usually observed in worldwide populations, which are encoded by the most frequent $G^{*} 01: 01, G^{*} 01: 03, G^{*} 01: 04$ and $G^{*} 01: 06$ allele families (Table 1), and which may influence HLA-G function (Fig. 2).

It is interesting to observe that the $\Delta \mathrm{C}$ deletion characteristic of the $G^{*} 01: 05 \mathrm{~N}$ allele [12] is frequently found in some populations and absent in others [108, 111, 117], being overrepresented in North Indian (15.4\%) and African Shona $(11.1 \%)$ populations compared to Danish $(1.0 \%)$ and Brazilian (0.97-4.17\%) populations. In addition, the $G^{*}$ 01:03 allele is overrepresented in North Indian (24.2\%) compared to African Shona (7.4\%) and Danish (4\%) populations (Table 1).

Considering all alleles described for the coding region of the $H L A-G$ gene, at least 24 exhibit a particular substitution detected only in a single or in a few individuals (Table 1). In fact, the number of detected $H L A-G$ alleles in distinct samples from different regions is frequently less than the total number $[82,89,105,108,111,118-122]$. Even in highly admixed populations, such as Brazilians, only 19 out of the $44 H L A-G$ alleles were detected considering two different samples, 3 of them being observed only in single individuals $[82,105,113,123]$.

Overall, the low protein variability observed for the $H L A-G$ gene corroborates evidence of its evolutionary pathway.

\section{$H L A-G$ polymorphism and disease associations}

HLA-G expression has been extensively evaluated in several disorders of distinct etiologies; however, $H L A-G$ gene polymorphism has not been studied to the same extent. Since the magnitude of HLA-G expression is regulated by the promoter and $3^{\prime}$ untranslated regions, many studies have focused on these regions, particularly on the $3^{\prime} \mathrm{UTR}$ polymorphic sites. In this section, we selected some disorders in which the tolerogenic role of HLA-G has been implicated on disease susceptibility, outcome or both, excluding pregnancy disorders, which will be discussed in another part of this series of HLA-G reviews.

\section{Chronic viral infections}

Viruses have evolved multiple strategies to subvert host immune surveillance and responses. Strategies such as the downregulation of classical MHC class I antigen prevent the display of viral peptides to escape lymphocyte $\mathrm{T}$ cytolysis [124]. In principle, virus-infected cells exhibiting downregulation of MHC class I molecules should be vulnerable to natural killer (NK) cell-mediated cytolysis. However, viruses have developed various mechanisms to impede NK cell recognition by inducing expression of HLA-G molecules [125, 126], which can suppress the 
Table 1 Frequencies of the HLA-G coding region alleles observed in selected populations

\begin{tabular}{|c|c|c|c|c|c|c|c|c|c|c|c|c|}
\hline Allele & $\begin{array}{l}\text { African } \\
\text { Shona }\end{array}$ & $\begin{array}{l}\text { African } \\
\text { American }\end{array}$ & $\begin{array}{l}\text { African } \\
\text { Guanaian }\end{array}$ & $\begin{array}{l}\text { Brazilians } \\
\text { (Southeast) } \\
\text { Cohort } 1\end{array}$ & $\begin{array}{l}\text { Brazilians } \\
\text { (Southeast) } \\
\text { Cohort } 2\end{array}$ & $\begin{array}{l}\text { North } \\
\text { India }^{c}\end{array}$ & Polish $^{\mathrm{d}}$ & Hutterite & Danish & German & Japanese & $\begin{array}{l}\text { Chinese } \\
\text { Han }^{c}\end{array}$ \\
\hline $\mathrm{G}^{*} 01: 01: 01: 01$ & 37.96 & 70.23 & 83.33 & 39.81 & $24.54^{\mathrm{a}}$ & 10.00 & 52.00 & 46.00 & 56.00 & 32.10 & 33.00 & 37.32 \\
\hline $\mathrm{G}^{*} 01: 01: 01: 02$ & & & & & - & & & & & & & \\
\hline $\mathrm{G}^{*} 01: 01: 01: 03$ & & & & & 0 & & & & & & & \\
\hline $\mathrm{G}^{*} 01: 01: 01: 04$ & & & & & 7.41 & & & & & & & \\
\hline $\mathrm{G}^{* 01: 01: 01: 05}$ & & & & & 11.11 & & & & & & & \\
\hline $\mathrm{G}^{*} 01: 01: 01: 06$ & & & & & - & & & & & & & \\
\hline $\mathrm{G}^{*} 01: 01: 02: 01$ & 15.74 & 5.95 & 2.38 & 19.90 & 15.28 & 16.25 & 30.50 & 20.00 & 25.00 & 36.30 & 16.00 & 11.64 \\
\hline $\mathrm{G}^{*} 01: 01: 02: 02$ & & & & & 0 & & & & & & & \\
\hline $\mathrm{G}^{*} 01: 01: 03: 01$ & - & 2.38 & 0 & 5.34 & 3.70 & 5.00 & 5.00 & 2.00 & 5.00 & 6.80 & 6.00 & 20.20 \\
\hline $\mathrm{G}^{*} 01: 01: 03: 02$ & - & & & & & & & & & & & \\
\hline$G^{*} 01: 01: 04$ & - & - & - & 0.49 & 0 & 7.50 & 0 & 4.40 & 0 & - & - & - \\
\hline $\mathrm{G}^{*} 01: 01: 05$ & - & - & - & 0 & 0.46 & 0 & 0 & - & 0 & - & - & - \\
\hline$G^{*} 01: 01: 06$ & - & - & - & 0.97 & 0 & - & 4.00 & - & - & - & - & - \\
\hline$G^{*} 01: 01: 07$ & - & - & - & 0 & 0 & 0 & 0 & - & 0 & 1.90 & - & - \\
\hline $\mathrm{G}^{* 01: 01: 08}$ & 6.94 & - & - & 4.37 & 0.93 & 0 & 4.50 & - & 1.00 & 9.10 & - & 5.48 \\
\hline$G^{*} 01: 01: 09$ & - & - & - & 0 & 0.46 & - & 1.00 & - & - & - & - & - \\
\hline $\mathrm{G}^{*} 01: 01: 11$ & - & - & - & 0.49 & 0 & - & 0 & - & - & - & - & - \\
\hline $\mathrm{G}^{*} 01: 01: 12$ & - & - & - & 0 & 0 & - & 0 & - & - & - & - & - \\
\hline $\mathrm{G}^{*} 01: 01: 13$ & - & - & - & 0 & 0 & - & 0 & - & - & - & - & - \\
\hline $\mathrm{G}^{*} 01: 01: 14$ & - & - & - & 0 & 0.46 & - & 0 & - & - & - & - & - \\
\hline G*01:01:15 & - & - & - & 0 & 0 & - & 0 & - & - & - & - & - \\
\hline G*01:01:16 & - & - & - & 0 & 0 & - & 0 & - & - & - & - & - \\
\hline $\mathrm{G}^{*} 01: 01: 17$ & - & - & - & 0 & 0 & - & 0 & - & - & - & - & - \\
\hline $\mathrm{G}^{*} 01: 01: 18$ & - & - & - & 0 & 0 & - & 0 & - & - & - & - & - \\
\hline $\mathrm{G}^{*} 01: 01: 19$ & - & - & - & 0 & 0 & - & 0 & - & - & - & - & - \\
\hline $\mathrm{G}^{*} 01: 02$ & - & - & - & 0 & 0 & 1.25 & 0 & - & 0 & - & - & - \\
\hline $\mathrm{G}^{*} 01: 03$ & 7.41 & - & - & 8.74 & 8.80 & 24.17 & 0 & 2.70 & 4.00 & 2.30 & - & 0.34 \\
\hline$G^{*} 01: 04: 01$ & 20.83 & 13.10 & 9.52 & 8.25 & 4.63 & 17.50 & 2.00 & 13.00 & 9.00 & 6.10 & 45.00 & 18.49 \\
\hline G*01:04:02 & - & - & - & 0 & 0 & - & 0 & - & - & - & - & 2.40 \\
\hline$G^{*} 01: 04: 03$ & - & - & - & 0 & 0.46 & - & 0 & - & 0 & - & - & 2.74 \\
\hline G*01:04:04 & - & - & - & 3.88 & 3.24 & - & 0 & - & - & - & - & - \\
\hline $\mathrm{G}^{*} 01: 04: 05$ & - & - & - & 0 & 0 & - & 0 & - & - & - & - & - \\
\hline $\mathrm{G}^{*} 01: 05 \mathrm{~N}$ & 11.11 & 8.33 & 4.76 & 0.97 & 4.17 & 15.42 & 1.50 & - & 1.00 & 2.30 & - & 1.37 \\
\hline $\mathrm{G}^{* 01: 06}$ & - & - & - & 4.85 & 6.48 & 2.92 & 0 & - & - & - & - & - \\
\hline $\mathrm{G}^{*} 01: 07$ & - & - & - & 0 & 0 & - & 0 & - & - & - & - & - \\
\hline $\mathrm{G}^{*} 01: 08$ & - & - & - & 0 & 0 & - & 0 & - & - & - & - & - \\
\hline $\mathrm{G}^{*} 01: 09$ & - & - & - & 0.49 & 0 & - & 0 & - & - & - & - & - \\
\hline $\mathrm{G}^{*} 01: 10$ & - & - & - & 0 & 0 & - & 0 & - & - & - & - & - \\
\hline $\mathrm{G}^{*} 01: 11$ & - & - & - & 0 & 0 & - & 0 & - & - & - & - & - \\
\hline $\mathrm{G}^{*} 01: 12$ & - & - & - & 0 & 0 & - & 0 & - & - & - & - & - \\
\hline $\mathrm{G}^{*} 01: 13 \mathrm{~N}$ & - & - & - & 0 & 0 & - & 0 & - & - & - & - & - \\
\hline $\mathrm{G}^{*} 01: 14$ & - & - & - & 0 & 0 & - & 0 & - & - & - & - & - \\
\hline $\mathrm{G}^{*} 01: 15$ & - & - & - & 0 & 0 & - & 0 & - & - & - & - & - \\
\hline $\mathrm{G}^{*} 01: 16$ & - & - & - & 0 & 0 & - & 0 & - & - & - & - & - \\
\hline Others & - & - & - & 1.45 & $7.41^{\mathrm{b}}$ & - & - & 12.00 & - & - & - & - \\
\hline
\end{tabular}


Table 1 continued

\begin{tabular}{llllllllllllll}
\hline Allele & $\begin{array}{l}\text { African } \\
\text { Shona }\end{array}$ & $\begin{array}{l}\text { African } \\
\text { American }\end{array}$ & $\begin{array}{l}\text { African } \\
\text { Guanaian }\end{array}$ & $\begin{array}{l}\text { Brazilians } \\
\text { (Southeast) } \\
\text { Cohort 1 }\end{array}$ & $\begin{array}{l}\text { Brazilians } \\
\text { (Southeast) } \\
\text { Cohort 2 }\end{array}$ & $\begin{array}{l}\text { North } \\
\text { India }^{c}\end{array}$ & Polish $^{\text {d }}$ & Hutterite & Danish & German Japanese & $\begin{array}{l}\text { Chinese } \\
\text { Han }^{c}\end{array}$ \\
\hline 2n & 216 & 84 & 84 & 206 & 216 & 240 & 200 & 160 & 104 & 264 & 108 & 292 \\
Reference & {$[108]$} & {$[118]$} & {$[118]$} & {$[105]$} & {$[82]$} & {$[111]$} & {$[119]$} & {$[120]$} & {$[89]$} & {$[121]$} & {$[89]$} & {$[122]$} \\
\hline
\end{tabular}

${ }^{a}$ The alleles $\mathrm{G}^{*}$ 01:01:01:01 and $\mathrm{G}^{*}$ 01:01:01:02 were pooled together

b This amount is due to typing ambiguities, not new alleles

c Group of fertile women

d Group of all individuals with in vitro fertilization

“-” Denotes an allele that was not evaluated

function of various immune cells [127-129]. The immunosuppressive properties of HLA-G might contribute to the susceptibility and persistence of viral infections.

Studies looking at the association between HLA-G expression and HIV-1 infection have yielded contradictory results. Increased soluble HLA-G levels [130] and increased surface expression of HLA-G on monocytes and $\mathrm{T}$ lymphocytes [126] were observed in antiretroviral (ART)-treated HIV-1-infected European Caucasians. In contrast, low levels of plasma soluble HLA-G were associated with HIV-1 infection in ART-naive Beninese commercial sex workers (CSW) [131]. The discrepancies observed in these studies may be due to several reasons: first, ART can induce surface expression of HLA-G on blood peripheral monocytes from HIV-1-infected patients $[132,133]$. Hence, the relatively high blood levels of HLA$\mathrm{G}$ observed in the European subjects could be due to ART and not to HIV-1 infection per se. Second, previous studies $[126,130]$ did not control for potential confounding factors that could influence HLA-G expression. Blood levels of soluble HLA-G are lower in men than in non-pregnant women [134], and during pregnancy the levels increase even more [135]. Third, cytokine production could influence HLA-G expression and vice versa. Interleukin (IL)-10 has been shown to induce HLA-G expression [136], and HLA-G can also stimulate IL-10 expression in peripheral blood monocytes [137]. Interestingly, plasma levels of IL-10 were lower in HIV-1-infected CSWs compared to both the HIV-1-uninfected CSW and non-CSW groups [138]. Fourth, HLA-G expression may fluctuate over the course of infection and may vary between different rates of disease progression. Indeed, longitudinal monitoring of plasma-soluble HLA-G levels in subjects with acute HIV infection undergoing different rates of disease progression showed that levels were elevated in the early phases of infection for all patients and remained high throughout follow-up in rapid progressors who responded to ART; however, soluble HLA-G were restored to normal levels in the chronic phase of infection in both untreated normal progressors and long-term nonprogressors [139]. Finally, $H L A-G$ gene polymorphism has to be taken into account since healthy individuals carrying the $H L A-G^{*} 01: 01: 03$ and $G^{*} 01: 05 \mathrm{~N}$ alleles have lower plasma-soluble HLA-G levels than subjects carrying the more frequent $H L A-G^{*} 01: 01: 01$ allele. In addition, individuals with the latter allele have lower plasma soluble HLA-G levels than those with the $H L A-G^{*} 01: 04: 01$ allele [84]. Moreover, the presence of a 14-bp sequence insertion in $H L A-G 3^{\prime}$ UTR has been associated with significantly reduced HLA-G mRNA levels [87] and lower levels of soluble HLA-G in the serum of healthy subjects $[63,140]$. In the study of CSWs from Benin, all subjects were non-pregnant women, and their reduced expression of soluble HLA-G in plasma was independently associated with both HIV-1 infection and the HLA-G $3^{\prime}$ UTR 14-bp sequence insertion homozygote genotype [131].

$H L A-G$ polymorphism is also associated with the risk of human immunodeficiency virus (HIV) infection. Indeed, the $H L A-G^{*} 01: 05 \mathrm{~N}$ allele was significantly associated with protection from HIV-1 infection, whereas the $H L A-G^{*}$ 01:01:08 allele was associated with an increased risk of HIV-1 infection in Zimbabwean women [141, 142].

Since the $H L A-G^{*} 01: 05 \mathrm{~N}$ allele does not encode complete HLA-G1 proteins [107], and since HLA-G1 is a major ligand by which HLA-G inhibits NK cell-mediated lysis [143], it has been postulated that the absence or reduced expression of HLA-G1 molecules in individuals carrying the $H L A-G^{*} 01: 05 \mathrm{~N}$ allele would allow NK cells to destroy HIV-infected cells, leading to protection from infection. The $H L A-G^{*} 01: 01: 08$ allele is defined by a synonymous substitution (proline) at codon 57 . Although discordance in $H L A-G$ codon 57 between a mother and her child has been reported to reduce the risk of HIV-1 vertical transmission in American Caucasians [144], this finding was not confirmed in the Zimbabwean population [145]. Because the polymorphism in codon 57 does not change the HLA-G amino acid composition and presumably its 
function, it is difficult at this time to envisage the mechanism by which such a silent mutation could have a direct influence on HIV transmission.

In addition, two independent studies have found an association between $H L A-G$ nucleotide sequences located in the $3^{\prime} \mathrm{UTR}$, including the $\mathrm{C}$ variant at position +3010 (others consider this position as +3777 ) and 14-bp deletion polymorphism, and decreased risk of HIV-1 vertical transmission [146, 147]. Moreover, two independent studies have demonstrated that the +3010 and 14-bp polymorphisms are in linkage disequilibrium, especially the association between the 14-bp insertion and the $+3010 \mathrm{C}$ allele $[82,148]$. The $3010 \mathrm{C}$ variant alone has no effect on vertical transmission of HIV-1 but, when linked with the 14-bp deletion allele, exerts a positive role on protection [148].

Associations between $H L A-G$ polymorphism and other chronic viral infections have also been described. Martinetti et al. [149] observed that the HLA-G $3^{\prime}$ UTR 14-bp deletion homozygote genotype and the presence of the $H L A-G^{*} 01: 04: 01$ allele that contains this deletion were both risk factors for vertical transmission of hepatitis $\mathrm{C}$ virus $(\mathrm{HCV})$, whereas the HLA-G*01:05N allele containing the 14-bp insertion polymorphism was associated with reduced risk of transmission. Homozygosity for the $\mathrm{C}$ variant at position +3142 in the $H L A-G 3^{\prime} \mathrm{UTR}$ region conferred protection against $\mathrm{HCV}$ infection among sickle cell disease patients [150]. Interestingly, the HLA$G 3^{\prime}$ UTR +3142 variant is in linkage disequilibrium with the 14-bp polymorphism and is thought to affect microRNA binding to the mRNA molecule, thus influencing HLA-G RNA turnover and translation [81, 82]. During acute human cytomegalovirus (hCMV) infection both membrane-bound and soluble HLA-G expression is upregulated in peripheral blood monocytes and bronchoalveolar macrophages [125, 151]. The $H L A-G$ 14-bp deletion homozygote genotype was associated with acute hCMV infection in children and higher hCMV DNA copy numbers in the urine of these children [152].

In neurotropic viral infections, herpes simplex virus type 1 and rabies virus upregulate the neuronal expression of HLA-G isoforms in both infected cells and neighboring uninfected cells [153]. Cell surface expression of HLA-G was restricted to rabies virus-infected neurons [154]; however, there are no $H L A-G$ polymorphism studies in these disorders.

Taken together, these observations suggest that, in the context of viral infections, the expression of HLA-G is a complex process modulated by many factors such as $H L A$ $G$ polymorphism, stage of infection, drug therapy, and cytokine expression patterns, which may contribute to an immunological environment affecting the outcome of infection.
Transplantation

Due to the scarcity of organs for transplantation, and due to the several mechanisms that contribute to graft rejection, much effort has been devoted to understanding the mechanisms associated with graft rejection and survival. Since the discovery in the 1990s that HLA-G played a relevant physiological role in the induction of maternal-fetal tolerance, the idea of investigating the role of HLA-G in allografting has taken hold. Several studies have been reported demonstrating that the presence of HLA-G in the allograft [155-158] or the increase of soluble HLA-G serum/plasma levels [159-166] are associated with better graft acceptance, increased graft survival or both.

Despite the large amount of information regarding the graft expression or the levels of soluble HLA-G, few studies have been conducted evaluating polymorphic sites in the $H L A-G$ gene, most of them evaluating only the 14-bp INDEL polymorphism in the 3'UTR. In kidney transplantation, the frequency of the 14-bp insertion/deletion alleles or genotypes revealed no significant differences when patients were compared to healthy controls, either in a Brazilian [167] or in an Italian cohort of patients [168]; however, the frequency of the 14-bp insertion homozygous genotype was increased in patients exhibiting acute rejection [167]. Similarly, in bone marrow transplantation for thalassemia, the 14-bp deletion homozygous genotype was associated with a higher risk of developing acute graftversus-host disease [169]. In contrast, for heart transplants, the 14-bp deletion homozygous genotype has been associated with higher levels of soluble HLA-G and higher bioavailability of cyclosporine [170]. Although the 14-bp insertion has been associated with a more stable mRNA [70], a fraction of HLA-G mRNA transcripts presenting the 14-bp insertion homozygous genotype has been associated with a lower production of HLA-G [63, 87]. According to these findings, the results regarding 14-bp INDEL polymorphism in transplantation are coherent, indicating that insertion homozygous genotypes (associated with decreased production of HLA-G) are associated with rejection or acute graft-versus-host disease, whereas the deletion homozygous genotype (associated with increased production) is associated with low rejection.

Besides the $3^{\prime} \mathrm{UTR}$, the coding region polymorphism has also been studied in renal transplant patients. It has been well recognized that HLA-A-B and -DR incompatibilities are associated with a poorer prognosis and shorter allograft survival; however, little attention has been paid to HLA$G$ locus incompatibility between donor and receptor, particularly considering that the HLA-G molecule is not a recognized peptide presenter molecule. On the other hand, the $H L A-G$ locus is in linkage disequilibrium with the $H L A-A$ locus, and the molecule has well-recognized 
tolerogenic features. The presence of two HLA-G matches was associated with lower risk of kidney rejection when compared to zero or one match. In addition, patients who were heterozygous for the $H L A-G$ alleles exhibiting synonymous/non-synonymous (S/NS) nucleotide variations had a higher chance to develop rejection in relation to those homozygous for $\mathrm{S} / \mathrm{S}$ or NS/NS alleles [113]. Since $H L A-G$ alleles exhibiting synonymous nucleotide variation may have distinct promoter or $3^{\prime} \mathrm{UTR}$, this study supports the importance of studying regulatory $H L A-G$ regions to understand the genetic mechanism associated with the production of HLA-G in transplants.

\section{Autoimmune disorders}

Autoimmune disorders encompass a heterogeneous group of diseases, exhibiting complex genetic inheritance, affecting virtually all organs or tissues, and producing a vast array of clinical features. Breakdown of the mechanisms that control central or peripheral tolerance in genetically susceptible individuals, usually triggered by environmental factors, is the major pathogenetic feature. In addition, many of these diseases share several susceptibility genes, particularly those encoded by MHC. Since classical HLA class I and II molecules are highly implicated in peptide presentation, and since disturbances of the $\mathrm{MHC} /$ peptide/T cell receptor interaction may drive the production of auto-reactive $\mathrm{T}$ lymphocytes or auto-reactive autoantibodies, the genes that encode these molecules have been the primary candidates associated with susceptibility to or protection against the development of autoimmunity. Besides MHC, some genes encoding molecules responsible for the negative control of the immune response, including CTLA-4, PTPN-22 and correlated genes, have been associated with distinct autoimmune disorders like systemic lupus erythematosus, rheumatoid arthritis, multiple sclerosis and type 1A diabetes mellitus [171-173]. Given that autoimmunity is caused by a breakdown of tolerance and HLA-G is as a tolerogenic molecule, HLA-G should be an adequate subject; however, little attention has been given to HLA-G tissue expression or genetic aspects.

Considering that the presence of soluble isoforms or HLA-G expression on affected tissue cells should lessen autoimmune manifestations, only few examples have shown such association. Tissue HLA-G expression has been observed in the skin of patients with systemic sclerosis, who exhibited a lower frequency of vascular cutaneous lesions, telangiectasias, inflammatory polyarthritis and increased survival after a 15-year follow-up [174]. In the demyelinating disorder multiple sclerosis, levels of soluble HLA-G in the cerebrospinal fluid of patients have been inversely associated with imaging findings indicative of disease activity [175]. Soluble HLA-
$\mathrm{G}$ levels were increased in patients with systemic lupus erythematosus in relation to controls; however, no correlation with disease activity was observed [176].

With respect to polymorphic sites in the $H L A-G$ gene, no association was found regarding the frequencies of the $-725 \mathrm{C} / \mathrm{G}$ (promoter region), exon 3 positions 129 and 130 $\Delta \mathrm{C}$ (coding region), and 14-bp INDEL ( $\left.3^{\prime} \mathrm{UTR}\right)$ in multiple sclerosis patients [73]. Increased frequencies of the 14-bp insertion allele as well as the insertion/insertion genotype were observed in systemic lupus erythematosus patients [115], whereas the heterozygous insertion/deletion genotype was associated with the disease activity index, photosensitivity and absence of arthritis [177]. The 14-bp deletion allele was overrepresented in patients exhibiting the juvenile form but not the adult form of rheumatoid arthritis, presenting no association with diseased severity or clinical manifestations [178]. In addition, the 14-bp insertion/insertion genotype was associated with increased production of soluble HLA-G levels and a better therapeutic response to methotrexate in adult rheumatoid arthritis patients [179].

Agnostic studies using genome-wide screens or fine mapping of the MHC region, conducted on large numbers of multiplex families, have unexpectedly identified the $H L A-G$ region as a susceptibility gene for type 1 diabetes mellitus [180] and for bronchial asthma, which is an immune-mediated chronic inflammatory disease [68]. The risk conferred by $H L A-G$ for diabetes mellitus patients was independent of that conferred by the well-recognized classical class II $H L A-D R B 1, \mathrm{DQB} 1$ and $D Q A 1$ alleles [181, 182]. The association of bronchial asthma with HLA-G has led investigators to evaluate the promoter and $3^{\prime} \mathrm{UTR}$ of the gene, reporting that the GG genotype of the -964G/A SNP was associated with asthma in children of affected mothers, whereas the AA genotype was associated with asthma in children of unaffected mothers, as previously mentioned [68]. In addition, the authors identified the SNP $+3142 \mathrm{C} / \mathrm{G}$ at the $3^{\prime} \mathrm{UTR}$ as a putative target site for miRNAs, strengthening the association of HLA-G and asthma [81].

Taken together, these findings seem to associate $H L A-G$ polymorphic sites with autoimmune disorders encompassing functional sites of the gene, i.e., the promoter and $3^{\prime}$ untranslated regions.

\section{Tumors}

Cancer cells display tumor-associated antigens coded by mutated or normal deregulated genes that, once presented by classical MHC class I molecules, may be recognized by the host immune system, being usually eliminated. Even in the presence of a competent immune system, neoplastic cells can grow and progress to very aggressive malignant 
lesions, evolving by tumor immunoediting, a process that comprises three major mechanisms. First, most immunogenic tumor cells are eliminated by cytotoxic $\mathrm{T}$ and $\mathrm{NK}$ cells. Second, tumor cells with reduced immunogenicity are selected. Third, variants that no longer respond to the host immune system are maintained [183-185]. HLA-G is supposed to play a pivotal role in cancer immunoediting by decreasing the elimination of tumor cells, inhibiting the cytotoxic function of T and NK cells, and by trogocytosis, i.e., the intercell transference of viable HLA-G molecules, rendering competent cytotoxic cells unresponsive to tumor antigens [186, 187].

The most common immune-escape mechanism in experimental or spontaneous tumors is the downregulation or lack of expression of classical HLA class I molecules, which directly affects cytotoxic $\mathrm{T}$ cell function against tumor cells. The loss of classical class I molecules is often associated with mutation in the $\beta 2$-microglobulin gene, which may affect class I expression level, producing unstable molecules. In addition, the loss of certain classical HLA class I alleles by microdeletions may lead to inefficient presentation of some immunodominant antigens [188]. In the absence of classical HLA class I molecules, NK cells become the major actors for tumor elimination. Similar to chronic viral infections, the microenvironment of the tumor or the transformed cell per se may induce HLA-G expression, impairing the activity of NK cells.

Several studies have demonstrated that various tumor lesions do present HLA-G transcription and protein expression [183]. To date, HLA-G expression has been detected in several tumor cells, exhibiting distinct patterns regarding the percentage of lesions expressing the molecule. Exemplifying, in cutaneous melanomas [189, 190], renal cell carcinomas [191], retinoblastomas [192], colorectal cancer [193], ovarian carcinomas [194, 195], endometrial adenocarcinomas [196], gastric cancer [197, 198], cutaneous T cell lymphomas [199, 200] and pancreatic ductal adenocarcinoma [201], among others [17, 202], at least $30 \%$ of these lesions exhibit HLA-G expression. In addition to tumor cell expression, HLA-G may also be detected in tumor infiltrating cells [183], which, allied to increased soluble HLA-G concentrations [203-206], may contribute to tumor progression.

Overall, most studies have evaluated HLA-G expression in tumor cells, tumor cell lines or even soluble HLA-G levels, and few genetic studies have been performed. Underlying these tumor-associated studies is the concept that some $H L A-G$ polymorphisms may influence HLA-G expression (promoter and $3^{\prime} \mathrm{UTR}$ polymorphisms), the pattern of alternative splicing of the primary transcript and mRNA turnover (coding region, including introns, and $3^{\prime}$ UTR polymorphisms). The regulatory sequences of the $H L A-G$ gene, as discussed earlier, may be induced by various factors present in the tumor microenvironment [207], since tumor-derived soluble factors may promote HLA-G expression [183]. Several lines of evidence have shown that the methylation status of the $H L A-G$ gene promoter is also crucial for the gene transcriptional activity $[66,67]$, and polymorphisms located at $\mathrm{CpG}$ sites surrounding the $H L A-G$ locus may affect the gene methylation pattern [64]. Regarding the $3^{\prime}$ UTR and coding region, the 14-bp insertion seems to occur at high frequency in renal cell carcinomas compared to the normal kidney epithelium; however, no correlation between the 14-bp INDEL polymorphism and the level of HLA-G expression has been found [191].

In human papillomavirus (HPV) infections, the coding region $G^{*} 01: 03$ and the $\mathrm{G}^{*} 01: 04$ alleles were associated with squamous intraepithelial lesions (SIL), and the $G^{*} 01: 01 / G^{*} 01: 04$ genotype was associated with highgrade lesions (HSIL). In addition, patients possessing the extended $G^{*}$ 01:04/+14-bp haplotype and harboring HPV16 and -18 co-infections were particularly susceptible to HSIL [208].

In bladder cancer, the $H L A-G$ locus was associated with susceptibility to transitional cell carcinoma (TCC) development and progression. The $G^{* 01: 04}$ allele family (especially the $G^{*}$ 01:04:04 allele) and the $G^{*} 01: 03$ allele were associated with a tobacco-dependent influence on TCC development. The $G^{*}$ 01:04 allele family was associated with progression to high-grade bladder tumor, irrespective of the smoking habit, while the $G^{*} 01: 03$ allele was associated with protection against TCC [123]. Curiously, the same $H L A-G$ coding region variations were found to influence both HPV-induced lesions and bladder cancer in studies conducted on two different samples of patients from the same geographical area (Southeast Brazil). Apparently, the $G^{*} 01: 04$ allele family $\left(G^{*} 01: 04: 01\right.$ and $G^{*}$ 01:04:04 being the most frequent alleles in Brazilians), which is often associated with HSIL, has also been associated with increased production of soluble HLA-G [84]. This is of particular importance since the $G^{* 01: 04}$ allele family occurs at high frequency in Brazilians (about $12 \%$ ) [105], as well as in worldwide populations studied so far, including African Shona (about 21\%) [110], North Indians (about 17.5\%) [111] and Danes (about 9\%) [89]. The higher expression of HLA-G associated with the $G^{*} 01: 04$ allele family is probably due to the presence of specific $5^{\prime}$ [61] or $3^{\prime} \mathrm{UTR}$ [82] haplotypes that are exclusive of these alleles. The $G^{*}$ 01:04 allele family presents the same $3^{\prime}$ UTR haplotype, encompassing two polymorphic sites previously associated with low HLA-G expression, $+3187 \mathrm{~A}$ and $+3142 \mathrm{G}$ [82]. In contrast, this family presents a unique promoter haplotype characterized by the presence of $-1155 \mathrm{~A}$ close to the locus control region (LCR), sharing specific combinations of polymorphic sites at several 
transcriptional factor binding sites [61]. Thus, it is possible that this promoter region segment may be responsible for the increased HLA-G production.

Knowledge of the tumor cell HLA-G expression profile as well as the typing of relevant polymorphic sites in the $H L A-G$ gene may discriminate patients prone to producing high amounts of HLA-G, individualizing future treatments targeting HLA-G.

\section{Concluding remarks}

In physiological conditions like pregnancy, the expression of HLA-G is useful to maintain tolerance of the semiallogeneic engraftment. In pathological conditions, the expression of HLA-G may be profitable or pernicious, depending on the specific disorder. Even considering individuals exhibiting the same type of disorder, some may express HLA-G, while others may not. Certainly, gene regulatory regions play a pivotal role in this process, and polymorphic sites observed in these regions may influence HLA-G production.

Whether or not a sick individual will express HLA-G depends on several factors: (1) transcriptional factors in the disease milieu that upregulate HLA-G expression; (2) presence of selected polymorphic sites in the promoter region that can be targeted for transcription factors; (3) magnitude of post-transcriptional factors that may degrade HLA-G mRNA, particularly, microRNAs that can target polymorphic sites at $3^{\prime}$ UTR; (4) structural features of the HLA-G molecule encoded by the alleles of that person, which are available to interact with HLA-G receptors; (5) intrinsic features of diseased tissue cells; (6) polymorphic sites on genes that encode the mediators involved in the pathogenesis of the disease; (7) the role of neighboring or distant genes epistatically acting on the HLA-G gene; and (8) the role of epigenetic factors, among others. Therefore, due to the complexity of this scenario, most studies have focused only on one or a few of these aspects, adding just a few scenes to a long motion picture that needs to be edited to show the epilogue. Much has to be learned regarding the regulation of HLA-G expression, to unveil individuals at risk to develop complications associated with the excess or scanty HLA-G production to individualize specific therapeutical approaches furnishing or inhibiting HLA-G.

Acknowledgements This work is supported by grants from: (1) The binational research cooperation program (CAPES/Brazil-COFECUB/ France project no. 653/09), (2) Commissariat à L'Energie Atomique (CEA), France, (3) Spanish Ministry of Health (FISS PI051039 and PI080838), Spanish Ministry of Foreign Affairs (A/9134/07 and A/17727/08) and three different Mutua Madrileña Automovilista grants. ECC is supported by a postdoctoral fellowship (07/58420-4) from FAPESP/Brazil, and MR by a career award from the Fonds de La Recherche en Santé du Québec, Canada.

Open Access This article is distributed under the terms of the Creative Commons Attribution Noncommercial License which permits any noncommercial use, distribution, and reproduction in any medium, provided the original author(s) and source are credited.

\section{References}

1. Robinson J, Waller MJ, Fail SC, Marsh SG (2006) The IMGT/ HLA and IPD databases. Hum Mutat 27:1192-1199

2. Carosella ED, Favier B, Rouas-Freiss N, Moreau P, Lemaoult J (2008) Beyond the increasing complexity of the immunomodulatory HLA-G molecule. Blood 111:4862-4870

3. Ishitani A, Sageshima N, Lee N, Dorofeeva N, Hatake K, Marquardt H, Geraghty DE (2003) Protein expression and peptide binding suggest unique and interacting functional roles for HLA-E, F, and G in maternal-placental immune recognition. J Immunol 171:1376-1384

4. Diehl M, Munz C, Keilholz W, Stevanovic S, Holmes N, Loke YW, Rammensee HG (1996) Nonclassical HLA-G molecules are classical peptide presenters. Curr Biol 6:305-314

5. Lee N, Malacko AR, Ishitani A, Chen MC, Bajorath J, Marquardt H, Geraghty DE (1995) The membrane-bound and soluble forms of HLA-G bind identical sets of endogenous peptides but differ with respect to TAP association. Immunity 3:591-600

6. Clements CS, Kjer-Nielsen L, McCluskey J, Rossjohn J (2007) Structural studies on HLA-G: implications for ligand and receptor binding. Hum Immunol 68:220-226

7. Fujii T, Ishitani A, Geraghty DE (1994) A soluble form of the HLA-G antigen is encoded by a messenger ribonucleic acid containing intron 4. J Immunol 153:5516-5524

8. Ishitani A, Geraghty DE (1992) Alternative splicing of HLA-G transcripts yields proteins with primary structures resembling both class I and class II antigens. Proc Natl Acad Sci USA 89:3947-3951

9. Paul P, Cabestre FA, Ibrahim EC, Lefebvre S, Khalil-Daher I, Vazeux G, Quiles RM, Bermond F, Dausset J, Carosella ED (2000) Identification of HLA-G7 as a new splice variant of the HLA-G mRNA and expression of soluble HLA-G5, -G6, and $-\mathrm{G} 7$ transcripts in human transfected cells. Hum Immunol 61:1138-1149

10. Carosella ED, Moreau P, Le Maoult J, Le Discorde M, Dausset J, Rouas-Freiss N (2003) HLA-G molecules: from maternal-fetal tolerance to tissue acceptance. Adv Immunol 81:199-252

11. Ober C, Aldrich CL (1997) HLA-G polymorphisms: neutral evolution or novel function? J Reprod Immunol 36:1-21

12. Suarez MB, Morales $P$, Castro MJ, Fernandez V, Varela P, Alvarez M, Martinez-Laso J, Arnaiz-Villena A (1997) A new HLA-G allele (HLA-G*0105N) and its distribution in the Spanish population. Immunogenetics 45:464-465

13. Lajoie J, Jeanneau A, Faucher MC, Moreau P, Roger M (2008) Characterisation of five novel HLA-G alleles with coding DNA base changes. Tissue Antigens 72:502-504

14. Boyson JE, Erskine R, Whitman MC, Chiu M, Lau JM, Koopman LA, Valter MM, Angelisova P, Horejsi V, Strominger JL (2002) Disulfide bond-mediated dimerization of HLA-G on the cell surface. Proc Natl Acad Sci USA 99:16180-16185

15. Gonen-Gross T, Achdout H, Arnon TI, Gazit R, Stern N, Horejsi V, Goldman-Wohl D, Yagel S, Mandelboim O (2005) The CD85J/leukocyte inhibitory receptor-1 distinguishes between 
conformed and beta 2-microglobulin-free HLA-G molecules. J Immunol 175:4866-4874

16. Shiroishi M, Kuroki K, Ose T, Rasubala L, Shiratori I, Arase H, Tsumoto K, Kumagai I, Kohda D, Maenaka K (2006) Efficient leukocyte Ig-like receptor signaling and crystal structure of disulfide-linked HLA-G dimer. J Biol Chem 281:10439-10447

17. Carosella ED, Moreau P, Lemaoult J, Rouas-Freiss N (2008) HLA-G: from biology to clinical benefits. Trends Immunol 29:125-132

18. Park B, Lee S, Kim E, Chang S, Jin M, Ahn K (2001) The truncated cytoplasmic tail of HLA-G serves a quality-control function in post-ER compartments. Immunity 15:213-224

19. Park B, Ahn K (2003) An essential function of tapasin in quality control of HLA-G molecules. J Biol Chem 278:14337-14345

20. Shiroishi M, Kuroki K, Rasubala L, Tsumoto K, Kumagai I, Kurimoto E, Kato K, Kohda D, Maenaka K (2006) Structural basis for recognition of the nonclassical MHC molecule HLA-G by the leukocyte Ig-like receptor B2 (LILRB2/LIR2/ILT4/ CD85d). Proc Natl Acad Sci USA 103:16412-16417

21. Gao GF, Willcox BE, Wyer JR, Boulter JM, O'Callaghan CA, Maenaka K, Stuart DI, Jones EY, Van Der Merwe PA, Bell JI, Jakobsen BK (2000) Classical and nonclassical class I major histocompatibility complex molecules exhibit subtle conformational differences that affect binding to CD8alphaalpha. J Biol Chem 275:15232-15238

22. Hsu KC, Chida S, Geraghty DE, Dupont B (2002) The killer cell immunoglobulin-like receptor (KIR) genomic region: geneorder, haplotypes and allelic polymorphism. Immunol Rev 190:40-52

23. LeMaoult J, Le Discorde M, Rouas-Freiss N, Moreau P, Menier C, McCluskey J, Carosella ED (2003) Biology and functions of human leukocyte antigen-G in health and sickness. Tissue Antigens 62:273-284

24. Apps R, Gardner L, Moffett A (2008) A critical look at HLA-G. Trends Immunol 29:313-321

25. Li C, Houser BL, Nicotra ML, Strominger JL (2009) HLA-G homodimer-induced cytokine secretion through HLA-G receptors on human decidual macrophages and natural killer cells. Proc Natl Acad Sci USA 106:5767-5772

26. Yan WH, Fan LA (2005) Residues Met76 and Gln79 in HLA-G alpha1 domain involve in KIR2DL4 recognition. Cell Res 15:176-182

27. Tan CY, Chong YS, Loganath A, Chan YH, Ravichandran J, Lee CG, Chong SS (2009) Possible gene-gene interaction of KIR2DL4 with its cognate ligand HLA-G in modulating risk for preeclampsia. Reprod Sci 16:1135-1143

28. Brown D, Trowsdale J, Allen R (2004) The LILR family: modulators of innate and adaptive immune pathways in health and disease. Tissue Antigens 64:215-225

29. Dietrich J, Cella M, Colonna M (2001) Ig-like transcript 2 (ILT2)/leukocyte Ig-like receptor 1 (LIR1) inhibits TCR signaling and actin cytoskeleton reorganization. J Immunol $166: 2514-2521$

30. Shiroishi M, Tsumoto K, Amano K, Shirakihara Y, Colonna M, Braud VM, Allan DS, Makadzange A, Rowland-Jones S, Willcox B, Jones EY, van der Merwe PA, Kumagai I, Maenaka K (2003) Human inhibitory receptors Ig-like transcript 2 (ILT2) and ILT4 compete with CD8 for MHC class I binding and bind preferentially to HLA-G. Proc Natl Acad Sci USA 100:88568861

31. Moreau P, Contu L, Alba F, Lai S, Simoes R, Orru S, Carcassi C, Roger M, Rabreau M, Carosella ED (2008) HLA-G gene polymorphism in human placentas: possible association of $\mathrm{G}^{*} 0106$ allele with preeclampsia and miscarriage. Biol Reprod 79:459-467
32. Tan CY, Ho JF, Chong YS, Loganath A, Chan YH, Ravichandran J, Lee CG, Chong SS (2008) Paternal contribution of HLA-G*0106 significantly increases risk for pre-eclampsia in multigravid pregnancies. Mol Hum Reprod 14:317-324

33. Puppo F, Contini P, Ghio M, Indiveri F (2002) Soluble HLA class I molecules/CD8 ligation trigger apoptosis of CD8+ cells by Fas/ Fas-ligand interaction. ScientificWorldJournal 2:421-423

34. Contini P, Ghio M, Poggi A, Filaci G, Indiveri F, Ferrone S, Puppo F (2003) Soluble HLA-A,-B,-C and -G molecules induce apoptosis in T and NK CD8+ cells and inhibit cytotoxic T cell activity through CD8 ligation. Eur J Immunol 33:125-134

35. Kuersten S, Goodwin EB (2003) The power of the 3' UTR: translational control and development. Nat Rev Genet 4:626637

36. Moreau P, Flajollet S, Carosella ED (2009) Nonclassical transcriptional regulation of HLA-G: An update. J Cell Mol Med 13(9B):2973-2989

37. van den Elsen PJ, Gobin SJ, van Eggermond MC, Peijnenburg A (1998) Regulation of MHC class I and II gene transcription: differences and similarities. Immunogenetics 48:208-221

38. Gobin SJ, Keijsers V, van Zutphen M, van den Elsen PJ (1998) The role of enhancer A in the locus-specific transactivation of classical and nonclassical HLA class I genes by nuclear factor kappa B. J Immunol 161:2276-2283

39. Gobin SJ, van Zutphen M, Woltman AM, van den Elsen PJ (1999) Transactivation of classical and nonclassical HLA class I genes through the IFN-stimulated response element. J Immunol 163:1428-1434

40. Steimle V, Durand B, Barras E, Zufferey M, Hadam MR, Mach B, Reith W (1995) A novel DNA-binding regulatory factor is mutated in primary MHC class II deficiency (bare lymphocyte syndrome). Genes Dev 9:1021-1032

41. Durand B, Sperisen P, Emery P, Barras E, Zufferey M, Mach B, Reith W (1997) RFXAP, a novel subunit of the RFX DNA binding complex is mutated in MHC class II deficiency. EMBO J 16:1045-1055

42. Masternak K, Barras E, Zufferey M, Conrad B, Corthals G, Aebersold R, Sanchez JC, Hochstrasser DF, Mach B, Reith W (1998) A gene encoding a novel RFX-associated transactivator is mutated in the majority of MHC class II deficiency patients. Nat Genet 20:273-277

43. Nagarajan UM, Louis-Plence P, DeSandro A, Nilsen R, Bushey A, Boss JM (1999) RFX-B is the gene responsible for the most common cause of the bare lymphocyte syndrome, an MHC class II immunodeficiency. Immunity 10:153-162

44. Moreno CS, Beresford GW, Louis-Plence P, Morris AC, Boss JM (1999) CREB regulates MHC class II expression in a CIITAdependent manner. Immunity 10:143-151

45. Mantovani R (1999) The molecular biology of the CCAATbinding factor NF-Y. Gene 239:15-27

46. Gobin SJ, Peijnenburg A, Keijsers V, van den Elsen PJ (1997) Site alpha is crucial for two routes of IFN gamma-induced MHC class I transactivation: the ISRE-mediated route and a novel pathway involving CIITA. Immunity 6:601-611

47. Lefebvre S, Moreau P, Dausset J, Carosella ED, Paul P (1999) Downregulation of HLA class I gene transcription in choriocarcinoma cells is controlled by the proximal promoter element and can be reversed by CIITA. Placenta 20:293-301

48. Gobin SJ, van Zutphen M, Westerheide SD, Boss JM, van den Elsen PJ (2001) The MHC-specific enhanceosome and its role in MHC class I and beta(2)-microglobulin gene transactivation. J Immunol 167:5175-5184

49. Solier C, Mallet V, Lenfant F, Bertrand A, Huchenq A, Le Bouteiller P (2001) HLA-G unique promoter region: functional implications. Immunogenetics 53:617-625 
50. Rousseau P, Paul P, O'Brien M, Dausset J, Carosella ED, Moreau P (2000) The X1 box of HLA-G promoter is a target site for RFX and Sp1 factors. Hum Immunol 61:1132-1137

51. Rousseau P, Masternak K, Krawczyk M, Reith W, Dausset J, Carosella ED, Moreau P (2004) In vivo, RFX5 binds differently to the human leucocyte antigen-E, $-\mathrm{F}$, and $-\mathrm{G}$ gene promoters and participates in HLA class I protein expression in a cell typedependent manner. Immunology 111:53-65

52. Schmidt CM, Ehlenfeldt RG, Athanasiou MC, Duvick LA, Heinrichs H, David CS, Orr HT (1993) Extraembryonic expression of the human MHC class I gene HLA-G in transgenic mice. evidence for a positive regulatory region located 1 kilobase $5^{\prime}$ to the start site of transcription. J Immunol 151:26332645

53. Yelavarthi KK, Schmidt CM, Ehlenfeldt RG, Orr HT, Hunt JS (1993) Cellular distribution of HLA-G mRNA in transgenic mouse placentas. J Immunol 151:3638-3645

54. Gobin SJ, Biesta P, de Steenwinkel JE, Datema G, van den Elsen PJ (2002) HLA-G transactivation by cAMP-response element-binding protein (CREB). An alternative transactivation pathway to the conserved major histocompatibility complex (MHC) class I regulatory routes. J Biol Chem 277:39525-39531

55. Lefebvre S, Berrih-Aknin S, Adrian F, Moreau P, Poea S, Gourand L, Dausset J, Carosella ED, Paul P (2001) A specific interferon (IFN)-stimulated response element of the distal HLA-G promoter binds IFN-regulatory factor 1 and mediates enhancement of this nonclassical class I gene by IFN-beta. J Biol Chem 276:6133-6139

56. Chu W, Gao J, Murphy WJ, Hunt JS (1999) A candidate interferon-gamma activated site (GAS element) in the HLA-G promoter does not bind nuclear proteins. Hum Immunol 60:1113-1118

57. Ibrahim EC, Morange M, Dausset J, Carosella ED, Paul P (2000) Heat shock and arsenite induce expression of the nonclassical class I histocompatibility HLA-G gene in tumor cell lines. Cell Stress Chaperones 5:207-218

58. Yie SM, Xiao R, Librach CL (2006) Progesterone regulates HLA-G gene expression through a novel progesterone response element. Hum Reprod 21:2538-2544

59. Flajollet S, Poras I, Carosella ED, Moreau P (2009) RREB-1 is a transcriptional repressor of HLA-G. J Immunol 183:6948-6959

60. Shi Y, Sawada J, Sui G, Affar el B, Whetstine JR, Lan F, Ogawa H, Luke MP, Nakatani Y (2003) Coordinated histone modifications mediated by a CtBP co-repressor complex. Nature 422:735-738

61. Tan Z, Shon AM, Ober C (2005) Evidence of balancing selection at the HLA-G promoter region. Hum Mol Genet 14:3619-3628

62. Hviid TV, Rizzo R, Melchiorri L, Stignani M, Baricordi OR (2006) Polymorphism in the $5^{\prime}$ upstream regulatory and $3^{\prime}$ untranslated regions of the HLA-G gene in relation to soluble HLA-G and IL-10 expression. Hum Immunol 67:53-62

63. Hviid TV, Rizzo R, Christiansen OB, Melchiorri L, Lindhard A, Baricordi OR (2004) HLA-G and IL-10 in serum in relation to HLA-G genotype and polymorphisms. Immunogenetics 56:135141

64. Ober C, Billstrand C, Kuldanek S, Tan Z (2006) The miscarriage-associated HLA-G $-725 \mathrm{G}$ allele influences transcription rates in JEG-3 cells. Hum Reprod 21:1743-1748

65. Langat DK, Morales PJ, Omwandho CO, Fazleabas AT (2007) Polymorphisms in the Paan-AG promoter influence NF-kappaB binding and transcriptional activity. Immunogenetics 59:359366

66. Moreau P, Mouillot G, Rousseau P, Marcou C, Dausset J, Carosella ED (2003) HLA-G gene repression is reversed by demethylation. Proc Natl Acad Sci USA 100:1191-1196
67. Mouillot G, Marcou C, Rousseau P, Rouas-Freiss N, Carosella ED, Moreau P (2005) HLA-G gene activation in tumor cells involves cis-acting epigenetic changes. Int J Cancer 113:928936

68. Nicolae D, Cox NJ, Lester LA, Schneider D, Tan Z, Billstrand C, Kuldanek S, Donfack J, Kogut P, Patel NM, Goodenbour J, Howard T, Wolf R, Koppelman GH, White SR, Parry R, Postma DS, Meyers D, Bleecker ER, Hunt JS, Solway J, Ober C (2005) Fine mapping and positional candidate studies identify HLA-G as an asthma susceptibility gene on chromosome $6 \mathrm{p} 21$. Am J Hum Genet 76:349-357

69. Auboeuf D, Honig A, Berget SM, O’Malley BW (2002) Coordinate regulation of transcription and splicing by steroid receptor coregulators. Science 298:416-419

70. Rousseau P, Le Discorde M, Mouillot G, Marcou C, Carosella ED, Moreau P (2003) The 14 bp deletion-insertion polymorphism in the $3^{\prime}$ UT region of the HLA-G gene influences HLA-G mRNA stability. Hum Immunol 64:1005-1010

71. Ober C, Aldrich CL, Chervoneva I, Billstrand C, Rahimov F, Gray HL, Hyslop T (2003) Variation in the HLA-G promoter region influences miscarriage rates. Am J Hum Genet 72:14251435

72. Doherty VL, Rush AN, Brennecke SP, Moses EK (2006) The $-56 \mathrm{~T}$ HLA-G promoter polymorphism is not associated with pre-eclampsia/eclampsia in Australian and New Zealand women. Hypertens Pregnancy 25:63-71

73. Kroner A, Grimm A, Johannssen K, Maurer M, Wiendl $\mathrm{H}$ (2007) The genetic influence of the nonclassical MHC molecule HLA-G on multiple sclerosis. Hum Immunol 68:422-425

74. Alvarez M, Piedade J, Balseiro S, Ribas G, Regateiro F (2009) HLA-G $3^{\prime}$-UTR SNP and 14-bp deletion polymorphisms in Portuguese and Guinea-Bissau populations. Int J Immunogenet $36: 361-366$

75. Aguilera A (2005) Cotranscriptional mRNP assembly: from the DNA to the nuclear pore. Curr Opin Cell Biol 17:242-250

76. Sommer P, Nehrbass U (2005) Quality control of messenger ribonucleoprotein particles in the nucleus and at the pore. Curr Opin Cell Biol 17:294-301

77. Saguez C, Olesen JR, Jensen TH (2005) Formation of exportcompetent mRNP: escaping nuclear destruction. Curr Opin Cell Biol 17:287-293

78. Veit TD, Chies JA (2009) Tolerance versus immune responsemicroRNAs as important elements in the regulation of the HLA-G gene expression. Transpl Immunol 20:229-231

79. Lee RC, Feinbaum RL, Ambros V (1993) The C. elegans heterochronic gene lin-4 encodes small RNAs with antisense complementarity to lin-14. Cell 75:843-854

80. Griffiths-Jones S, Grocock RJ, van Dongen S, Bateman A, Enright AJ (2006) miRBase: microRNA sequences, targets and gene nomenclature. Nucleic Acids Res 34:D140-D144

81. Tan Z, Randall G, Fan J, Camoretti-Mercado B, BrockmanSchneider R, Pan L, Solway J, Gern JE, Lemanske RF, Nicolae $\mathrm{D}$, Ober C (2007) Allele-specific targeting of microRNAs to HLA-G and risk of asthma. Am J Hum Genet 81:829-834

82. Castelli EC, Mendes-Junior CT, Deghaide NH, de Albuquerque RS, Muniz YC, Simoes RT, Carosella ED, Moreau P, Donadi EA (2009) The genetic structure of $3^{\prime}$ untranslated region of the HLA-G gene: polymorphisms and haplotypes. Genes Immun 11(2):134-141

83. Geraghty DE, Koller BH, Orr HT (1987) A human major histocompatibility complex class I gene that encodes a protein with a shortened cytoplasmic segment. Proc Natl Acad Sci USA 84:9145-9149

84. Rebmann V, van der Ven K, Passler M, Pfeiffer K, Krebs D, Grosse-Wilde H (2001) Association of soluble HLA-G plasma levels with HLA-G alleles. Tissue Antigens 57:15-21 
85. Hiby SE, King A, Sharkey A, Loke YW (1999) Molecular studies of trophoblast HLA-G: polymorphism, isoforms, imprinting and expression in preimplantation embryo. Tissue Antigens 53:1-13

86. O'Brien M, McCarthy T, Jenkins D, Paul P, Dausset J, Carosella ED, Moreau P (2001) Altered HLA-G transcription in preeclampsia is associated with allele specific inheritance: possible role of the HLA-G gene in susceptibility to the disease. Cell Mol Life Sci 58:1943-1949

87. Hviid TV, Hylenius S, Rorbye C, Nielsen LG (2003) HLA-G allelic variants are associated with differences in the HLA-G mRNA isoform profile and HLA-G mRNA levels. Immunogenetics 55:63-79

88. Harrison GA, Humphrey KE, Jakobsen IB, Cooper DW (1993) A 14 bp deletion polymorphism in the HLA-G gene. Hum Mol Genet 2:2200

89. Hviid TV (2006) HLA-G in human reproduction: aspects of genetics, function and pregnancy complications. Hum Reprod Update 12:209-232

90. Castelli EC, Moreau P, Oya e Chiromatzo A, Mendes-Junior CT, Veiga-Castelli LC, Yaghi L, Giuliatti S, Carosella ED, Donadi EA (2009) In silico analysis of microRNAS targeting the HLA-G $3^{\prime}$ untranslated region alleles and haplotypes. Hum Immunol 70:1020-1025

91. Yie SM, Li LH, Xiao R, Librach CL (2008) A single base-pair mutation in the $3^{\prime}$-untranslated region of HLA-G mRNA is associated with pre-eclampsia. Mol Hum Reprod 14:649-653

92. Alvarez M, Santos P, Martinho A, Simoes O, Abade A, BredaCoimbra H (1999) HLA-G genetic polymorphism in 57 Portuguese white families studied by PCR-RFLP and PCR-SSOP. Transplant Proc 31:1829-1831

93. Watkins DI, Chen ZW, Hughes AL, Evans MG, Tedder TF, Letvin NL (1990) Evolution of the MHC class I genes of a New World primate from ancestral homologues of human non-classical genes. Nature 346:60-63

94. Alvarez-Tejado M, Martinez-Laso J, Garcia-de-la-Torre C, Varela P, Recio MJ, Allende L, Gomez-Casado E, ArnaizVillena A (1998) Description of two Mhc-C-related sequences in the New World monkey Saguinus oedipus. Eur J Immunogenet 25:409-417

95. Parga-Lozano C, Reguera R, Gomez-Prieto P, Arnaiz-Villena A (2009) Evolution of major histocompatibility complex G and C and natural killer receptors in primates. Hum Immunol 70:1035-1040

96. Watkins DI, Letvin NL, Hughes AL, Tedder TF (1990) Molecular cloning of cDNA that encode MHC class I molecules from a New World primate (Saguinus oedipus). Natural selection acts at positions that may affect peptide presentation to $\mathrm{T}$ cells. J Immunol 144:1136-1143

97. Arnaiz-Villena A, Morales P, Gomez-Casado E, Castro MJ, Varela P, Rojo-Amigo R, Martinez-Laso J (1999) Evolution of MHC-G in primates: a different kind of molecule for each group of species. J Reprod Immunol 43:111-125

98. Arnaiz-Villena A, Martinez-Laso J, Alvarez M, Castro MJ, Varela P, Gomez-Casado E, Suarez B, Recio MJ, VargasAlarcon G, Morales P (1997) Primate Mhc-E and -G alleles. Immunogenetics 46:251-266

99. Burton FD (1995) The multimedia guide to the non-human primates : print version. Prentice Hall Canada, Scarborough, Ont

100. Alvarez-Tejado M, Martinez-Laso J, Garcia-Torre C, Varela P, Perez-Blas M, Moreno MA, Gomez-Casado E, Arnaiz-Villena A (1998) Description of a new kind of MHC DNA sequence in Saguinus oedipus (cotton-top tamarin). Eur J Immunogenet 25:287-292

101. Castro MJ, Morales P, Fernandez-Soria V, Suarez B, Recio MJ, Alvarez M, Martin-Villa M, Arnaiz-Villena A (1996) Allelic diversity at the primate Mhc-G locus: exon 3 bears stop codons in all Cercopithecinae sequences. Immunogenetics 43:327-336

102. Fernandez-Soria VM, Morales P, Castro MJ, Suarez B, Recio MJ, Moreno MA, Paz-Artal E, Arnaiz-Villena A (1998) Transcription and weak expression of HLA-DRB6: a gene with anomalies in exon 1 and other regions. Immunogenetics 48:16-21

103. Howard M, Frizzell RA, Bedwell DM (1996) Aminoglycoside antibiotics restore CFTR function by overcoming premature stop mutations. Nat Med 2:467-469

104. Peltola M, Chiatayat D, Peltonen L, Jalanko A (1994) Characterization of a point mutation in aspartylglucosaminidase gene: evidence for a readthrough of a translational stop codon. Hum Mol Genet 3:2237-2242

105. Castelli EC, Mendes-Junior CT, Donadi EA (2007) HLA-G alleles and HLA-G 14 bp polymorphisms in a Brazilian population. Tissue Antigens 70:62-68

106. Castro MJ, Morales P, Martinez-Laso J, Allende L, Rojo-Amigo R, Gonzalez-Hevilla M, Varela P, Moreno A, Garcia-Berciano M, Arnaiz-Villena A (2000) Evolution of MHC-G in humans and primates based on three new 3'UT polymorphisms. Hum Immunol 61:1157-1163

107. Ober C, Aldrich C, Rosinsky B, Robertson A, Walker MA, Willadsen S, Verp MS, Geraghty DE, Hunt JS (1998) HLA-G1 protein expression is not essential for fetal survival. Placenta 19:127-132

108. Matte C, Lacaille J, Zijenah L, Ward B, Roger M (2002) HLA-G exhibits low level of polymorphism in indigenous East Africans. Hum Immunol 63:495-501

109. Castro MJ, Morales P, Rojo-Amigo R, Martinez-Laso J, Allende L, Varela P, Garcia-Berciano M, Guillen-Perales J, ArnaizVillena A (2000) Homozygous HLA-G*0105N healthy individuals indicate that membrane-anchored HLA-G1 molecule is not necessary for survival. Tissue Antigens 56:232-239

110. Matte C, Lacaille J, Zijenah L, Ward B, Roger M (2000) HLA-G and HLA-E polymorphisms in an indigenous African population. The ZVITAMBO Study Group. Hum Immunol 61:1150-1156

111. Abbas A, Tripathi P, Naik S, Agrawal S (2004) Analysis of human leukocyte antigen (HLA)-G polymorphism in normal women and in women with recurrent spontaneous abortions. Eur J Immunogenet 31:275-278

112. Sipak-Szmigiel O, Cybulski C, Lubinski J, Ronin-Walknowska E (2008) HLA-G polymorphism in a Polish population and reproductive failure. Tissue Antigens 71:67-71

113. Pirri A, Contieri FC, Benvenutti R, Bicalho Mda G (2009) A study of HLA-G polymorphism and linkage disequilibrium in renal transplant patients and their donors. Transpl Immunol 20:143-149

114. Sipak-Szmigiel O, Ronin-Walknowska E, Cybulski C, Plonka T, Lubinski J (2007) Antigens HLA-G, sHLA-G and sHLA-class I in reproductive failure. Folia Histochem Cytobiol 45(Suppl 1):S137-S141

115. Rizzo R, Hviid TV, Govoni M, Padovan M, Rubini M, Melchiorri L, Stignani M, Carturan S, Grappa MT, Fotinidi M, Ferretti S, Voss A, Laustrup H, Junker P, Trotta F, Baricordi OR (2008) HLA-G genotype and HLA-G expression in systemic lupus erythematosus: HLA-G as a putative susceptibility gene in systemic lupus erythematosus. Tissue Antigens 71:520-529

116. Lajoie J, Boivin AA, Jeanneau A, Faucher MC, Roger M (2009) Identification of six new HLA-G alleles with non-coding DNA base changes. Tissue Antigens 73:379-380

117. Mendes-Junior CT, Castelli EC, Simoes AL, Donadi EA (2007) Absence of the HLA-G*0105N allele in Amerindian populations from the Brazilian Amazon Region: a possible role of natural selection. Tissue Antigens 70:330-334 
118. Ishitani A, Kishida M, Sageshima N, Yashiki S, Sonoda S, Hayami M, Smith AG, Hatake K (1999) Re-examination of HLA-G polymorphism in African Americans. Immunogenetics 49:808-811

119. Sipak-Szmigiel O, Cybulski C, Wokolorczyk D, Lubinski J, Kurzawa R, Baczkowski T, Radwan M, Radwan P, RoninWalknowska E (2009) HLA-G polymorphism and in vitro fertilization failure in a Polish population. Tissue Antigens 73:348-352

120. Ober C, Rosinsky B, Grimsley C, van der Ven K, Robertson A, Runge A (1996) Population genetic studies of HLA-G: allele frequencies and linkage disequilibrium with HLA-A1. J Reprod Immunol 32:111-123

121. van der Ven K, Skrablin S, Engels G, Krebs D (1998) HLA-G polymorphisms and allele frequencies in Caucasians. Hum Immunol 59:302-312

122. Yan WH, Fan LA, Yang JQ, Xu LD, Ge Y, Yao FJ (2006) HLA$\mathrm{G}$ polymorphism in a Chinese Han population with recurrent spontaneous abortion. Int J Immunogenet 33:55-58

123. Castelli EC, Mendes-Junior CT, Viana de Camargo JL, Donadi EA (2008) HLA-G polymorphism and transitional cell carcinoma of the bladder in a Brazilian population. Tissue Antigens 72:149-157

124. Hansen TH, Bouvier M (2009) MHC class I antigen presentation: learning from viral evasion strategies. Nat Rev Immunol 9:503-513

125. Onno M, Pangault C, Le Friec G, Guilloux V, Andre P, Fauchet R (2000) Modulation of HLA-G antigens expression by human cytomegalovirus: specific induction in activated macrophages harboring human cytomegalovirus infection. J Immunol 164:6426-6434

126. Lozano JM, Gonzalez R, Kindelan JM, Rouas-Freiss N, Caballos R, Dausset J, Carosella ED, Pena J (2002) Monocytes and $\mathrm{T}$ lymphocytes in HIV-1-positive patients express HLA-G molecule. Aids 16:347-351

127. Le Gal FA, Riteau B, Sedlik C, Khalil-Daher I, Menier C, Dausset J, Guillet JG, Carosella ED, Rouas-Freiss N (1999) HLA-G-mediated inhibition of antigen-specific cytotoxic $\mathrm{T}$ lymphocytes. Int Immunol 11:1351-1356

128. Lila N, Rouas-Freiss N, Dausset J, Carpentier A, Carosella ED (2001) Soluble HLA-G protein secreted by allo-specific CD4+ $\mathrm{T}$ cells suppresses the allo-proliferative response: a CD4+ T cell regulatory mechanism. Proc Natl Acad Sci USA 98:1215012155

129. Park GM, Lee S, Park B, Kim E, Shin J, Cho K, Ahn K (2004) Soluble HLA-G generated by proteolytic shedding inhibits NKmediated cell lysis. Biochem Biophys Res Commun 313:606611

130. Donaghy L, Gros F, Amiot L, Mary C, Maillard A, Guiguen C, Gangneux JP (2007) Elevated levels of soluble non-classical major histocompatibility class I molecule human leucocyte antigen (HLA)-G in the blood of HIV-infected patients with or without visceral leishmaniasis. Clin Exp Immunol 147:236-240

131. Lajoie J, Massinga Loembe M, Poudrier J, Guedou F, Pepin J, Labbe AC, Alary M, Roger M (2010) Blood soluble human leukocyte antigen $\mathrm{G}$ levels are associated with human immunodeficiency virus type 1 infection in Beninese commercial sex workers. Hum Immunol 71:182-185

132. Cabello A, Rivero A, Garcia MJ, Lozano JM, Torre-Cisneros J, Gonzalez R, Duenas G, Galiani MD, Camacho A, Santamaria M, Solana R, Montero C, Kindelan JM, Pena J (2003) HAART induces the expression of HLA-G on peripheral monocytes in HIV-1 infected individuals. Hum Immunol 64:1045-1049

133. Rivero A, Lozano JM, Gonzalez R, Garcia-Jurado G, Camacho A, Torres-Cisneros J, Pena J (2007) Nucleoside reverse transcriptase inhibitors are able and protease inhibitors unable to induce the tolerogenic molecule HLA-G1 on monocytes from HIV-1 infected patients. Hum Immunol 68:303-306

134. Rudstein-Svetlicky N, Loewenthal R, Horejsi V, Gazit E (2007) HLA-G levels in serum and plasma. Tissue Antigens 69(Suppl 1):140-142

135. Hackmon R, Hallak M, Krup M, Weitzman D, Sheiner E, Kaplan B, Weinstein Y (2004) HLA-G antigen and parturition: maternal serum, fetal serum and amniotic fluid levels during pregnancy. Fetal Diagn Ther 19:404-409

136. Moreau P, Adrian-Cabestre F, Menier C, Guiard V, Gourand L, Dausset J, Carosella ED, Paul P (1999) IL-10 selectively induces HLA-G expression in human trophoblasts and monocytes. Int Immunol 11:803-811

137. van der Meer A, Lukassen HG, van Cranenbroek B, Weiss EH, Braat DD, van Lierop MJ, Joosten I (2007) Soluble HLA-G promotes Th1-type cytokine production by cytokine-activated uterine and peripheral natural killer cells. Mol Hum Reprod 13:123-133

138. Lajoie J, Poudrier J, Massinga-Loembe M, Guedou F, AgossaGbenafa C, Labbe AC, Alary M, Roger M (2008) Differences in immunoregulatory cytokine expression patterns in the systemic and genital tract compartments of HIV-1-infected commercial sex workers in Benin. Mucosal Immunol 1:309-316

139. Lajoie J, Fontaine J, Tremblay C, Routy JP, Poudrier J, Roger M (2009) Persistence of high levels of blood soluble human leukocyte antigen-G is associated with rapid progression of HIV infection. AIDS 23:1437-1440

140. Hviid TV, Hylenius S, Lindhard A, Christiansen OB (2004) Association between human leukocyte antigen-G genotype and success of in vitro fertilization and pregnancy outcome. Tissue Antigens 64:66-69

141. Matte C, Lajoie J, Lacaille J, Zijenah LS, Ward BJ, Roger M (2004) Functionally active HLA-G polymorphisms are associated with the risk of heterosexual HIV-1 infection in African women. AIDS 18:427-431

142. Lajoie J, Hargrove J, Zijenah LS, Humphrey JH, Ward BJ, Roger M (2006) Genetic variants in nonclassical major histocompatibility complex class I human leukocyte antigen (HLA)E and HLA-G molecules are associated with susceptibility to heterosexual acquisition of HIV-1. J Infect Dis 193:298-301

143. Navarro F, Llano M, Bellon T, Colonna M, Geraghty DE, Lopez-Botet M (1999) The ILT2(LIR1) and CD94/NKG2A NK cell receptors respectively recognize HLA-G1 and HLA-E molecules co-expressed on target cells. Eur J Immunol 29:277283

144. Aikhionbare FO, Hodge T, Kuhn L, Bulterys M, Abrams EJ, Bond VC (2001) Mother-to-child discordance in HLA-G exon 2 is associated with a reduced risk of perinatal HIV-1 transmission. AIDS 15:2196-2198

145. Matte C, Zijenah LS, Lacaille J, Ward B, Roger M (2002) Mother-to-child human leukocyte antigen $\mathrm{G}$ concordance: no impact on the risk of vertical transmission of HIV-1. AIDS $16: 2491-2494$

146. Aikhionbare FO, Kumaresan K, Shamsa F, Bond VC (2006) HLA-G DNA sequence variants and risk of perinatal HIV-1 transmission. AIDS Res Ther 3:28

147. Fabris A, Catamo E, Segat L, Morgutti M, Arraes LC, de LimaFilho JL, Crovella S (2009) Association between HLA-G 3'UTR 14-bp polymorphism and HIV vertical transmission in Brazilian children. AIDS 23:177-182

148. Segat L, Catamo E, Fabris A, Padovan L, Morgutti M, Crovella S (2009) HLA-G $3^{\prime}$ UTR haplotypes and HIV vertical transmission. AIDS 23:1916-1918

149. Martinetti M, Pacati I, Cuccia M, Badulli C, Pasi A, Salvaneschi L, Minola E, De Silvestri A, Iannone AM, Maccabruni A (2006) Hierarchy of baby-linked immunogenetic risk factors in the 
vertical transmission of hepatitis $\mathrm{C}$ virus. Int $\mathrm{J}$ Immunopathol Pharmacol 19:369-378

150. Cordero EA, Veit TD, da Silva MA, Jacques SM, Silla LM, Chies JA (2009) HLA-G polymorphism influences the susceptibility to $\mathrm{HCV}$ infection in sickle cell disease patients. Tissue Antigens 74:308-313

151. Yan WH, Lin A, Chen BG, Chen SY (2009) Induction of both membrane-bound and soluble HLA-G expression in active human cytomegalovirus infection. J Infect Dis 200:820-826

152. Zheng XQ, ZhuF, Shi WW, Lin A, Yan WH (2009) The HLA-G $14 \mathrm{bp}$ insertion/deletion polymorphism is a putative susceptible factor for active human cytomegalovirus infection in children. Tissue Antigens 74(4):317-321

153. Lafon M, Prehaud C, Megret F, Lafage M, Mouillot G, Roa M, Moreau P, Rouas-Freiss N, Carosella ED (2005) Modulation of HLA-G expression in human neural cells after neurotropic viral infections. J Virol 79:15226-15237

154. Megret F, Prehaud C, Lafage M, Moreau P, Rouas-Freiss N, Carosella ED, Lafon M (2007) Modulation of HLA-G and HLAE expression in human neuronal cells after rabies virus or herpes virus simplex type 1 infections. Hum Immunol 68:294-302

155. Sheshgiri R, Rouas-Freiss N, Rao V, Butany J, Ramzy D, Krawice-Radanne I, Ross HJ, Carosella ED, Delgado DH (2008) Myocardial HLA-G reliably indicates a low risk of acute cellular rejection in heart transplant recipients. J Heart Lung Transplant 27:522-527

156. Crispim JC, Duarte RA, Soares CP, Costa R, Silva JS, MendesJunior CT, Wastowski IJ, Faggioni LP, Saber LT, Donadi EA (2008) Human leukocyte antigen-G expression after kidney transplantation is associated with a reduced incidence of rejection. Transpl Immunol 18:361-367

157. Creput C, Durrbach A, Menier C, Guettier C, Samuel D, Dausset J, Charpentier B, Carosella ED, Rouas-Freiss N (2003) Human leukocyte antigen-G (HLA-G) expression in biliary epithelial cells is associated with allograft acceptance in liver-kidney transplantation. J Hepatol 39:587-594

158. Brugiere O, Thabut G, Pretolani M, Krawice-Radanne I, Dill C, Herbreteau A, Poras I, Moreau P, Colombat M, Danel C, Dehoux M, Fournier M, Carosella ED, Rouas-Freiss N (2009) Immunohistochemical study of HLA-G expression in lung transplant recipients. Am J Transplant 9:1427-1438

159. Kaneku, H. (2006) Detection of soluble HLA-G and its correlation with kidney transplant outcome. Clin Transpl, 447-454

160. Lila N, Amrein C, Guillemain R, Chevalier P, Fabiani JN, Carpentier A (2007) Soluble human leukocyte antigen-G: a new strategy for monitoring acute and chronic rejections after heart transplantation. J Heart Lung Transplant 26:421-422

161. Luque J, Torres MI, Aumente MD, Lozano JM, Garcia-Jurado G, Gonzalez R, Alvarez-Lopez MR, Arizon JM, Pena J (2006) sHLA-G levels in the monitoring of immunosuppressive therapy and rejection following heart transplantation. Transpl Immunol 17:70-73

162. Qiu J, Terasaki PI, Miller J, Mizutani K, Cai J, Carosella ED (2006) Soluble HLA-G expression and renal graft acceptance. Am J Transplant 6:2152-2156

163. Luque J, Torres MI, Aumente MD, Marin J, Garcia-Jurado G, Gonzalez R, Pascual D, Guerra N, Lopez-Rubio F, AlvarezLopez MR, Arizon JM, Pena J (2006) Soluble HLA-G in heart transplantation: their relationship to rejection episodes and immunosuppressive therapy. Hum Immunol 67:257-263

164. Basturk B, Karakayali F, Emiroglu R, Sozer O, Haberal A, Bal D, Haberal M (2006) Human leukocyte antigen-G, a new parameter in the follow-up of liver transplantation. Transplant Proc 38:571-574

165. Rebmann V, Bartsch D, Wunsch A, Mollenbeck P, Golda T, Viebahn R, Grosse-Wilde H (2009) Soluble total human leukocyte antigen class I and human leukocyte antigen-G molecules in kidney and kidney/pancreas transplantation. Hum Immunol 70:995-999

166. Wu J, Zhang W, Hernandez-Lopez P, Fabelo E, Parikh M, Mulloy LL, Horuzsko A (2009) Isoforms of human leukocyte antigen-G and their inhibitory receptors in human kidney allograft acceptance. Hum Immunol 70:988-994

167. Crispim JC, Mendes-Junior CT, Wastowski IJ, Costa R, Castelli EC, Saber LT, Donadi EA (2008) Frequency of insertion/deletion polymorphism in exon 8 of HLA-G and kidney allograft outcome. Tissue Antigens 71:35-41

168. Piancatelli D, Maccarone D, Liberatore G, Parzanese I, Clemente K, Azzarone R, Pisani F, Famulari A, Papola F (2009) HLA-G 14-bp insertion/deletion polymorphism in kidney transplant patients with metabolic complications. Transplant Proc 41:1187-1188

169. La Nasa G, Littera R, Locatelli F, Lai S, Alba F, Caocci G, Lisini D, Nesci S, Vacca A, Piras E, Bernardo ME, Di CesareMerlone A, Orru S, Carcassi C (2007) The human leucocyte antigen-G 14-basepair polymorphism correlates with graft-versus-host disease in unrelated bone marrow transplantation for thalassaemia. Br J Haematol 139:284-288

170. Torres MI, Luque J, Lorite P, Isla-Tejera B, Palomeque T, Aumente MD, Arizon J, Pena J (2009) 14-Base pair polymorphism of human leukocyte antigen-G as genetic determinant in heart transplantation and cyclosporine therapy monitoring. Hum Immunol 70:830-835

171. Baranzini SE (2009) The genetics of autoimmune diseases: a networked perspective. Curr Opin Immunol 21:596-605

172. Silva GL, Junta CM, Sakamoto-Hojo ET, Donadi EA, LouzadaJunior P, Passos GA (2009) Genetic susceptibility loci in rheumatoid arthritis establish transcriptional regulatory networks with other genes. Ann N Y Acad Sci 1173:521-537

173. Silva GL, Junta CM, Mello SS, Garcia PS, Rassi DM, Sakamoto-Hojo ET, Donadi EA, Passos GA (2007) Profiling metaanalysis reveals primarily gene coexpression concordance between systemic lupus erythematosus and rheumatoid arthritis. Ann N Y Acad Sci 1110:33-46

174. Wastowski IJ, Sampaio-Barros PD, Amstalden EM, Palomino GM, Marques-Neto JF, Crispim JC, Biral AC, Rassi DM, Carosella ED, Moreau P, Donadi EA (2009) HLA-G expression in the skin of patients with systemic sclerosis. J Rheumatol 36:1230-1234

175. Fainardi E, Rizzo R, Melchiorri L, Stignani M, Castellazzi M, Tamborino C, Paolino E, Tola MR, Granieri E, Baricordi OR (2008) CSF levels of soluble HLA-G and Fas molecules are inversely associated to MRI evidence of disease activity in patients with relapsing-remitting multiple sclerosis. Multiple Scler 14:446-454

176. Rosado S, Perez-Chacon G, Mellor-Pita S, Sanchez-Vegazo I, Bellas-Menendez C, Citores MJ, Losada-Fernandez I, MartinDonaire T, Rebolleda N, Perez-Aciego P (2008) Expression of human leukocyte antigen-G in systemic lupus erythematosus. Hum Immunol 69:9-15

177. Veit TD, Cordero EA, Mucenic T, Monticielo OA, Brenol JC, Xavier RM, Delgado-Canedo A, Chies JA (2009) Association of the HLA-G $14 \mathrm{bp}$ polymorphism with systemic lupus erythematosus. Lupus 18:424-430

178. Veit TD, Vianna P, Scheibel I, Brenol CV, Brenol JC, Xavier RM, Delgado-Canedo A, Gutierrez JE, Brandalize AP, SchulerFaccini L, Chies JA (2008) Association of the HLA-G 14-bp insertion/deletion polymorphism with juvenile idiopathic arthritis and rheumatoid arthritis. Tissue Antigens 71:440-446

179. Rizzo R, Rubini M, Govoni M, Padovan M, Melchiorri L, Stignani M, Carturan S, Ferretti S, Trotta F, Baricordi OR (2006) HLA-G 14-bp polymorphism regulates the methotrexate 
response in rheumatoid arthritis. Pharmacogenet Genomics $16: 615-623$

180. Eike MC, Becker T, Humphreys K, Olsson M, Lie BA (2009) Conditional analyses on the T1DGC MHC dataset: novel associations with type 1 diabetes around HLA-G and confirmation of HLA-B. Genes Immun 10:56-67

181. She JX (1996) Susceptibility to type I diabetes: HLA-DQ and DR revisited. Immunol Today 17:323-329

182. Fernandes AP, Louzada-Junior P, Foss MC, Donadi EA (2002) HLA-DRB1, DQB1, and DQA1 allele profile in Brazilian patients with type 1 diabetes mellitus. Ann N Y Acad Sci 958:305-308

183. Carosella ED, Horuzsko A (2007) HLA-G and cancer. Semin Cancer Biol 17(6):411-421

184. Dunn GP, Koebel CM, Schreiber RD (2006) Interferons, immunity and cancer immunoediting. Nat Rev Immunol 6:836-848

185. Dunn GP, Old LJ, Schreiber RD (2004) The three Es of cancer immunoediting. Annu Rev Immunol 22:329-360

186. LeMaoult J, Caumartin J, Daouya M, Favier B, Le Rond S, Gonzalez A, Carosella ED (2007) Immune regulation by pretenders: cell-to-cell transfers of HLA-G make effector T cells act as regulatory cells. Blood 109:2040-2048

187. Caumartin J, Favier B, Daouya M, Guillard C, Moreau P, Carosella ED, LeMaoult J (2007) Trogocytosis-based generation of suppressive NK cells. EMBO J 26:1423-1433

188. Algarra I, Garcia-Lora A, Cabrera T, Ruiz-Cabello F, Garrido F (2004) The selection of tumor variants with altered expression of classical and nonclassical MHC class I molecules: implications for tumor immune escape. Cancer Immunol Immunother 53:904-910

189. Paul P, Rouas-Freiss N, Khalil-Daher I, Moreau P, Riteau B, Le Gal FA, Avril MF, Dausset J, Guillet JG, Carosella ED (1998) HLA-G expression in melanoma: a way for tumor cells to escape from immunosurveillance. Proc Natl Acad Sci U S A 95:4510-4515

190. Rebmann V, Wagner S, Grosse-Wilde H (2007) HLA-G expression in malignant melanoma. Semin Cancer Biol 17:422-429

191. Seliger B, Schlaf G (2007) Structure, expression and function of HLA-G in renal cell carcinoma. Semin Cancer Biol 17:444-450

192. Adithi M, Kandalam M, Ramkumar HL, Subramanian A, Venkatesan N, Krishnakumar S (2006) Retinoblastoma: expression of HLA-G. Ocul Immunol Inflamm 14:207-213

193. Fukushima Y, Oshika Y, Nakamura M, Tokunaga T, Hatanaka $\mathrm{H}$, Abe Y, Yamazaki H, Kijima H, Ueyama Y, Tamaoki N (1998) Increased expression of human histocompatibility leukocyte antigen-G in colorectal cancer cells. Int J Mol Med 2:349-351

194. Lin A, Yan WH, Xu HH, Gan MF, Cai JF, Zhu M, Zhou MY (2007) HLA-G expression in human ovarian carcinoma counteracts NK cell function. Ann Oncol 18:1804-1809

195. Menier C, Prevot S, Carosella ED, Rouas-Freiss N (2009) HLA$\mathrm{G}$ is expressed in advanced-stage ovarian carcinoma of high grade histology. Hum Immunol 70(12):1006-1009
196. Barrier BF, Kendall BS, Sharpe-Timms KL, Kost ER (2006) Characterization of human leukocyte antigen-G (HLA-G) expression in endometrial adenocarcinoma. Gynecol Oncol 103:25-30

197. Ishigami S, Natsugoe S, Miyazono F, Nakajo A, Tokuda K, Matsumoto M, Okumura H, Douchi T, Hokita S, Aikou T (2006) HLA-G expression in gastric cancer. Anticancer Res 26:24672472

198. Yie SM, Yang H, Ye SR, Li K, Dong DD, Lin XM (2007) Expression of human leukocyte antigen G (HLA-G) correlates with poor prognosis in gastric carcinoma. Ann Surg Oncol 14:2721-2729

199. Bezuhly M, Howlett A, Colp P, Conrad DM, Walsh N, Rowden G, Morris SF, Langley RG (2008) Quantitative HLA-G expression in metastasising and non-metastasising primary thin cutaneous melanomas. Dermatology 217:281-283

200. Urosevic M, Willers J, Mueller B, Kempf W, Burg G, Dummer R (2002) HLA-G protein up-regulation in primary cutaneous lymphomas is associated with interleukin-10 expression in large cell T-cell lymphomas and indolent B-cell lymphomas. Blood 99:609-617

201. Cirulli V, Zalatan J, McMaster M, Prinsen R, Salomon DR, Ricordi C, Torbett BE, Meda P, Crisa L (2006) The class I HLA repertoire of pancreatic islets comprises the nonclassical class $\mathrm{Ib}$ antigen HLA-G. Diabetes 55:1214-1222

202. Seliger B, Abken H, Ferrone S (2003) HLA-G and MIC expression in tumors and their role in anti-tumor immunity. Trends Immunol 24:82-87

203. Ugurel S, Rebmann V, Ferrone S, Tilgen W, Grosse-Wilde H, Reinhold U (2001) Soluble human leukocyte antigen-G serum level is elevated in melanoma patients and is further increased by interferon-alpha immunotherapy. Cancer 92:369-376

204. Singer G, Rebmann V, Chen YC, Liu HT, Ali SZ, Reinsberg J, McMaster MT, Pfeiffer K, Chan DW, Wardelmann E, GrosseWilde H, Cheng CC, Kurman RJ, Shih Ie M (2003) HLA-G is a potential tumor marker in malignant ascites. Clin Cancer Res 9:4460-4464

205. Leleu X, Le Friec G, Facon T, Amiot L, Fauchet R, Hennache B, Coiteux V, Yakoub-Agha I, Dubucquoi S, Avet-Loiseau H, Mathiot C, Bataille R, Mary JY (2005) Total soluble HLA class I and soluble HLA-G in multiple myeloma and monoclonal gammopathy of undetermined significance. Clin Cancer Res 11:7297-7303

206. Gros F, Sebti Y, de Guibert S, Branger B, Bernard M, Fauchet $\mathrm{R}$, Amiot L (2006) Soluble HLA-G molecules increase during acute leukemia, especially in subtypes affecting monocytic and lymphoid lineages. Neoplasia 8:223-230

207. Tripathi P, Agrawal S (2006) Non-classical HLA-G antigen and its role in the cancer progression. Cancer Invest 24:178-186

208. Simoes RT, Goncalves MA, Castelli EC, Junior CM, Bettini JS, Discorde ML, Duarte G, Quintana SM, Simoes AL, Moreau P, Carosella ED, Soares EG, Donadi EA (2009) HLA-G polymorphisms in women with squamous intraepithelial lesions harboring human papillomavirus. Mod Pathol 22:1075-1082 